\title{
Indium and selenium distribution in the Neves-Corvo deposit, Iberian Pyrite Belt, Portugal
}

\author{
J. R. S. Carvalho ${ }^{1,2, *}$, J. M. R. S. Relvas ${ }^{1}$, A. M. M. Pinto $^{1}$, M. Frenzel $^{3}$, J. Krause ${ }^{3}$, J. Gutzmer ${ }^{3}$,

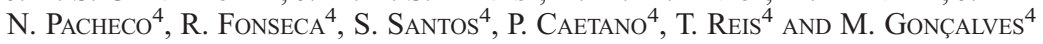 \\ 1 Instituto Dom Luiz, Faculdade de Ciências, Universidade de Lisboa, 1749-016 Lisboa, Portugal \\ 2 Sustainable Innovation Centre, ISQ, Qeiras Taguspark, 2740-120 Porto Salvo, Portugal \\ 3 Helmholtz-Zentrum Dresden-Rossendorf, Institut Freiberg für Ressourcentechnologie, Chemnitzer Str. 40, 09599 \\ Freiberg, Germany \\ 4 Somincor - Lundin Mining, Neves Corvo mine, 7780 Castro Verde, Portugal
}

[Received 1 March 2017; Accepted 10 October 2017; Associate Editor: Nigel Cook]

\section{ABSTRACT}

High concentrations of indium (In) and selenium (Se) have been reported in the Neves-Corvo volcanic-hosted massive sulfide deposit, Portugal. The distribution of these ore metals in the deposit is complex as a result of the combined effects of early ore-forming processes and late tectonometamorphic remobilization. The In and $\mathrm{Se}$ contents are higher in $\mathrm{Cu}$-rich ore types, and lower in $\mathrm{Zn}$-rich ore types. At the deposit scale, both $\mathrm{In}$ and $\mathrm{Se}$ correlate positively with $\mathrm{Cu}$, whereas their correlations with $\mathrm{Zn}$ are close to zero. This argues for a genetic connection between $\mathrm{Cu}$, In and Se in terms of metal sourcing and precipitation. However, re-distribution and re-concentration of In and Se associated with tectonometamorphic deformation are also processes of major importance for the actual distribution of these metals throughout the whole deposit. Although minor roquesite and other In-bearing phases were recognized, it is clear that most In within the deposit is found incorporated within sphalerite and chalcopyrite. When chalcopyrite and sphalerite coexist, the In content in sphalerite (avg. $1400 \mathrm{ppm}$ ) is, on average, 2-3 times higher than in chalcopyrite (avg. $660 \mathrm{ppm}$ ). The In content in stannite (avg. $1.3 \mathrm{wt} . \%$ ) is even higher than in sphalerite, but the overall abundance of stannite is subordinate to either sphalerite or chalcopyrite. Selenium is dispersed widely between many different ore minerals, but galena is the main Se-carrier. On average, the Se content in galena is $\sim 50$ times greater than in either chalcopyrite (avg. $610 \mathrm{ppm}$ ) or sphalerite (avg. $590 \mathrm{ppm}$ ). The copper concentrate produced at Neves-Corvo contains very significant In $(+\mathrm{Se})$ content, well above economic values if the copper smelters recovered it. Moreover, the high In content of sphalerite from some $\mathrm{Cu}-\mathrm{Zn}$ ores, or associated with shear structures, could possibly justify, in the future, a selective exploitation strategy for the production of an In-rich zinc concentrate.

Keywords: Neves-Corvo, indium, selenium.

\section{Introduction}

THE Neves-Corvo volcanic-hosted massive sulfide (VHMS) deposit stands out among the numerous

*E-mail: jrcarvalho@fc.ul.pt

https://doi.org/10.1180/minmag.2017.081.079
Iberian Pyrite Belt (IPB) deposits, as well as among other VHMS deposits worldwide, due to its unique massive cassiterite mineralization (up to $60 \%$ $\mathrm{SnO}_{2}$ ), extremely high-grade cupriferous ores (the initial resource was $34 \mathrm{Mt} @ 8.5 \% \mathrm{Cu}$; the mine operated for 5 years before the head grade dropped below $10 \% \mathrm{Cu}$; the maximum $\mathrm{Cu}$ grade in a production face exceeded $40 \% \mathrm{Cu}$ ), and large

This paper is part of a special issue entitled 'Critical-metal mineralogy and ore genesis'. The Applied Mineralogy Group of the Mineralogical Society and the IMA Commission on Ore Mineralogy have contributed to the costs of Open Access publication for this paper.

(C) The Mineralogical Society 2018. This is an Open Access article, distributed under the terms of the Creative Commons Attribution licence (http://creativecommons.org/licenses/by/4.0/), which permits unrestricted re-use, distribution, and reproduction in any medium, provided the original work is properly cited. 
resources of Zn-rich ores (>117 Mt @, 5.86wt.\% $\mathrm{Zn})$. Today, the deposit is one of the leading producers of copper and zinc concentrates in the European Union (Gurmendi, 2013). In addition to this, the Neves-Corvo mine is also known to contain very significant amounts of indium (In) and selenium (Se). Previous studies have revealed significant In and Se abundances associated with tin and cupriferous ores. However, the spatial distribution and the mineral speciation of these added-value metals in its ores have only been reported to a limited extent (e.g. Pinto et al., 1997, 2014; Serranti et al., 1997, 2002; Relvas, 2000; Schwarz-Schampera, 2000; Benzaazoua et al., 2002, 2003; Gaspar, 2002; Schwarz-Schampera and Herzig, 2002; Carvalho et al., 2013, 2014, 2015; Frenzel et al., 2015). This contribution focuses for the first time on the overall distributions of In and Se in the Neves-Corvo deposit and their spatial relationships, abundances and mineral speciation. The study was developed in close collaboration with the Neves-Corvo mine geology department and benefited from the detailed geological knowledge of the deposit, powerful 3D software tools and huge geochemical database available at Somincor-Lundin Mining. The elucidation of abundances in In and Se, their spatial distribution and their relationships and geochemical affinities in the deposit not only addresses important issues in the general context of the IPB, it also represents an important assessment for the operation of the mine. Further investigation is nevertheless needed to obtain a detailed understanding of In- and Se-mineral speciation in this complex, multi-stage and multi-sourced deposit.

\section{The Neves-Corvo deposit}

The Neves-Corvo deposit is located at the southeastern termination of the Rosário-Neves-Corvo antiform, in the Portuguese part of the IPB, and is composed of seven known massive and stringer sulfide orebodies (the Neves, Corvo, Graça, Lombador, Zambujal, Semblana and Monte Branco orebodies; Fig. 1). Excluding the stockwork zones, these orebodies contain a total of 369 million tonnes (Mt) of massive sulfide mineralization, of which $198 \mathrm{Mt}$ are massive sulfide ores@2.10\% $\mathrm{Cu}, 4.28 \% \mathrm{Zn}, 0.92 \% \mathrm{~Pb}, 0.13 \% \mathrm{Sn}, 59.13 \mathrm{ppm} \mathrm{Ag}$ and $0.47 \mathrm{ppm} \mathrm{Au}$. Recognition of the local stratigraphic sequence came about as a result of thorough palynostratigraphic and physical volcanology studies (Oliveira et al., 1997, 2004; Pereira et al., 2004; Rosa et al., 2005, 2008), coupled with surface and underground mapping and observation by several authors, including a number of on-site mine geologists (e.g. Albouy et al., 1981; Leca et al., 1983, 1985; Carvalho and Ferreira, 1994; Silva et al., 1997; Pacheco et al., 1998). Collectively, these studies have revealed a very complex local lithostratigraphic sequence, which extends from the late Famennian (Upper Devonian) to the late Visean (Lower Carboniferous), and comprises an autochthonous and an allochthonous sequence which, between them, make up the three main lithostratigraphic units recognized in the IPB (from base to top): the Phyllite-Quartzite Formation (PQ Group; Givetian-Strunian, base unknown), the Volcanic-Sedimentary Complex (VSC; FamenianUpper Visean) and the Baixo-Alentejo Flysch Group (Mértola Formation; Late Visean; Oliveira et al., 2004, 2013). The massive sulfide mineralization $(\sim 359-360 \mathrm{Ma})$ is generally hosted on top of the Neves Formation, in direct contact with either dark shales, or felsic volcanic rocks (Oliveira et al., 2004; Kaufmann, 2006; Rosa et al., 2008). However, at the Lombador orebody the massive sulfide mineralization may also contact directly with the PQ Group rocks, thus indicating a variable basin palaeomorphology which reflects a very dynamic and compartmented rift-basin environment during ore formation in the region (Carvalho et al., 2013). The tectonically piled up sequences are separated by major low-angle thrust faults that repeat sections of the VSC and of the Mértola Formation under low-grade metamorphism (up to lower greenschist facies). This structural setting was a consequence of synorogenic, NW-trending and SW-verging fold-thrust thin-skinned tectonics (from the Upper Visean onwards; Munhá, 1990; Silva et al., 1990; Oliveira et al., 2004). Late sub-vertical faults, represented predominantly by left-lateral faults with a $\mathrm{N}-\mathrm{S}$ to $\mathrm{N} 20 \mathrm{E}$ and $\mathrm{N} 40 \mathrm{E}$ to N60E strike, and right-lateral faults with a $\mathrm{N} 30 \mathrm{~W}$ to $\mathrm{E}-\mathrm{W}$ strike disrupted the whole sequence.

The footwall hydrothermal alteration zonation recognized at the Neves-Corvo deposit comprises a chlorite ( \pm donbassite)-dominated core (alteration zone I) that is surrounded by a sericite-dominated zone (alteration zone IIa), which becomes richer in sodium towards its peripheral envelope (alteration zone IIb) (Relvas et al., 2006a). The alteration mineralogy, geochemistry and stable isotopes indicate that ore fluids at the Neves-Corvo deposit were hotter and more acidic than typical IPB oreforming fluids (Relvas et al., 2006a,b). 


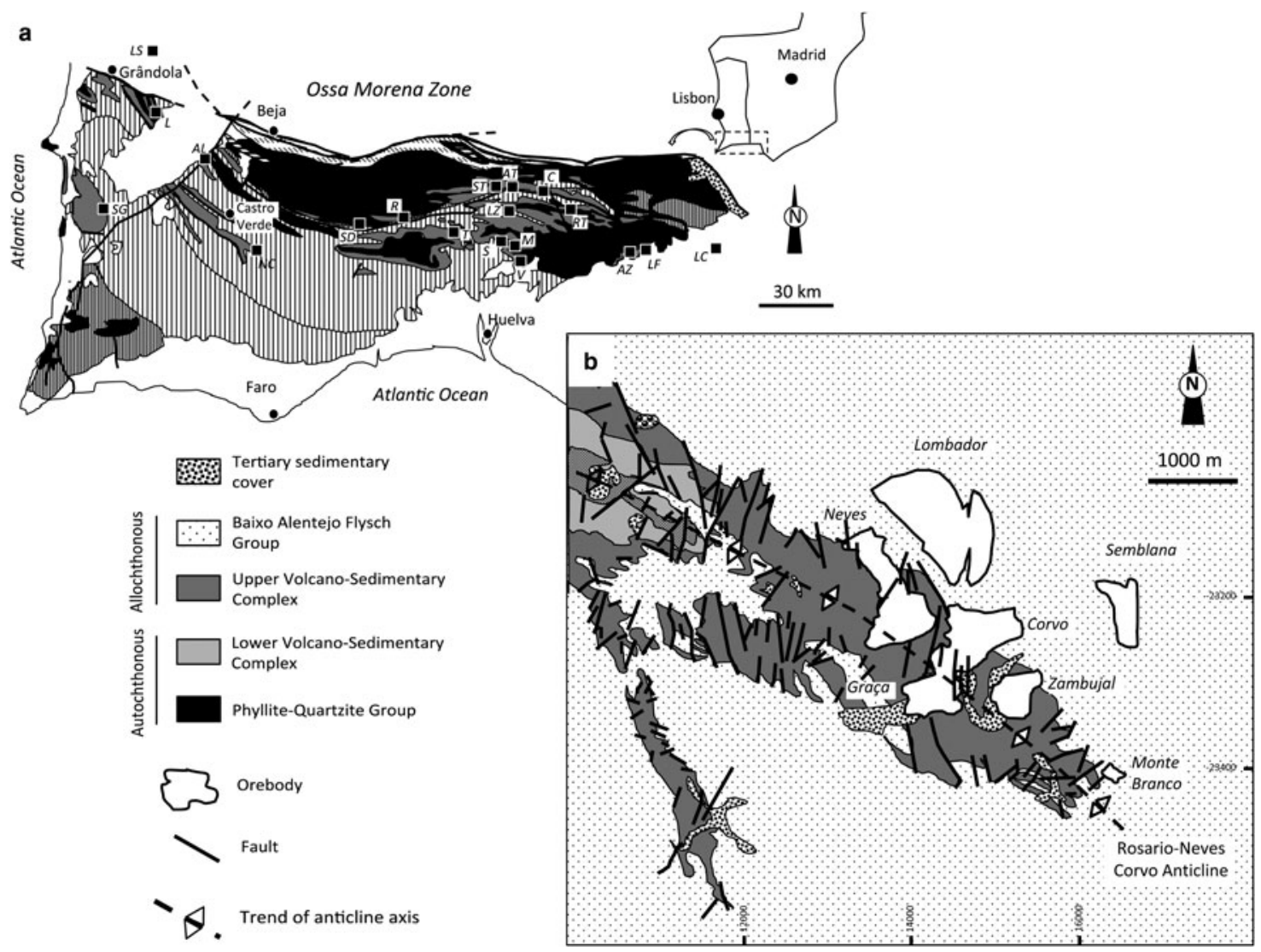

FIG. 1. (a) Geological map of the IPB, with location of the Neves-Corvo deposit (adapted from Oliveira, 1990; Carvalho et al., 1999, and references therein). (b) Geological map of the Neves-Corvo mine area showing the location of the seven orebodies currently known in the deposit (modified after Oliveira et al., 2004, and references therein). AT - Aguas Tenidas; AL - Aljustrel; AZ - Aznalcollar; C - Concepcion; L - Lousal; LC - Las Cruces; LF - Los Frailes; LG - Salgadinho; LS - Lagoa Salgada; LZ - La Zarza; M - Migollas; NC - Neves Corvo; R - Romanera; RT - Rio Tinto; S - Sotiel; SG - Salgadinho; SD - São Domingos; ST - San Telmo; T - Tharsis; V - Masa Valverde. 
The exceptional ore geochemistry and stable isotope signatures, and the uniqueness of some of the radiogenic isotope signatures of the NevesCorvo ores are consistent with a magmatichydrothermal model for the deposit (Relvas et al., 2001, 2002, 2006a,b; Huston et al., 2011). Furthermore, recent, IPB-like, $\mathrm{Sr}, \mathrm{Nd}$ and $\mathrm{Pb}$ isotope data from the Lombador orebody highlight the equally relevant role of footwall leaching for the metal budget of the deposit (Carvalho, 2016). A large, focused, long-lived, multi-sourced magmatic-hydrothermal ore-forming system is thought to have been responsible for this outstanding mineralization. In addition to a major derivation of metals leached from the IPB footwall sequence, which include contributions from an evolved, deepseated, seawater-derived, metal-rich brine equilibrated with the PQ metasediments, a direct magmatic contribution is envisaged to have been added to the Neves-Corvo metal budget and to have contributed, in different moments of the oreforming process, to the $\mathrm{Sn}$ contents of the deposit, as well as to part of its $\mathrm{Cu}$, In and $\mathrm{Se}$ contents (Relvas et al., 2001, 2006a,b; Munhá et al., 2005; Jorge et al., 2007; Huston et al., 2011; Carvalho, 2016).

\section{Sampling and methods}

The study of In and Se abundance and distribution in the Neves-Corvo deposit was based on a systematic drill-core sampling campaign run at the giant, Zn-rich Lombador orebody, and on a more specific and targeted sampling strategy at the Corvo, Graça, Zambujal and Neves orebodies, directed at settings known to host $\mathrm{Zn}$ - and $\mathrm{Cu}-\mathrm{Zn}$ massive sulfide ores that are particularly rich in both In and Se. The ore types considered in this study follow the categories defined in the mine, which include stockwork ores, either Zn-rich (FZ), or Cu-rich (FC); and $\mathrm{Cu}$ (MC), $\mathrm{Cu}-\mathrm{Zn}$ (MCZ), Zn (MZ), $\mathrm{Zn}-\mathrm{Pb}(\mathrm{MZP})$ and $\mathrm{Pb}(\mathrm{MP})$ massive sulfide ores. Barren, pyritic stockwork and massive sulfide mineralization are named $\mathrm{FE}$ and $\mathrm{ME}$, respectively.

Selection of the studied drill holes was guided by the Vulcan ${ }^{\circledR}$ 3D software available at SomincorLundin Mining, and took into consideration the spatial distribution of the drill holes, ore types intersected and metal grades, particularly $\mathrm{Cu}, \mathrm{Zn}$, In and Se. At the Lombador orebody, 16 drill holes were selected, distributed along $12 \mathrm{NE}-\mathrm{SW}$ crosssections that cover the south, central (E and W) and north sectors of the orebody. At the remaining orebodies, a total of 15 drill holes was selected for study: three at the Neves orebody, five at the SW area of the Graça orebody, two at the Zambujal orebody and five at the SE area of the Corvo orebody (Fig. 2).

A total of 330 polished thin and round sections, corresponding to $>300$ representative samples, were inspected under both reflected and transmitted light, and a detailed petrographic study and refinement of the micro-textures, mineralogy and mineral assemblages was undertaken. All samples were prepared for microscopic observation at the Faculty of Sciences, University of Lisbon, Portugal. A sub-set of 50 samples, representative of the different ore types, was selected to yield quantitative estimates of the ore-sulfide mineralogy by means of point counting (1000 points per section).

After detailed optical microscopic inspection, a total of 1758 electron probe micro analysis (EPMA) points were performed on 66 carefully selected ore samples representative of the different ore types collected. These analyses were carried out at the Department of Earth Sciences, University of Toronto (UT), Canada, using a Cameca SX-50/51 (DCI 1300 DLL) electron microprobe equipped with three tunable wavelength-dispersive spectrometers, and at the Helmholtz Institute of Freiberg for Resource Technology (HIF), Freiberg, Germany, using a JEOL JXA-8530F electron microprobe equipped with five tunable wavelength-dispersive spectrometers. For each set of probed samples, the beam was aligned at the beginning of each working session, and calibration of the standard X-ray intensities of the elements to be measured were run both at the beginning and at the end of each working session to check for reproducibility. Unknown and standard intensities were corrected for dead time, and the standard intensities were corrected for standard drift over time. Interference corrections were applied to As$\mathrm{Pb}$, to $\mathrm{S}-\mathrm{Co}$ and to $\mathrm{In}-\mathrm{Sn}$. The matrix-correction method was either ZAF, or Phi-Rho-Z. The beam diameter was $=1 \mu \mathrm{m}$. The operating conditions used at the UT were: beam energy of $25 \mathrm{keV}$ and current of $50 \mathrm{nA}$, whereas at HIF they were beam energy of $20 \mathrm{KeV}$ and current of $20 \mathrm{nA}$. The corresponding minimum detection limits (MDL; mean background $+3 \sigma$ ) are indicated in Table 1. Many grains were analysed twice, in both microprobe facilities, yielding very consistent results, with deviations systematically $<2.4 \%$. Nevertheless, in order to guarantee maximum quantification confidence, in particular for the In and Se analytical 


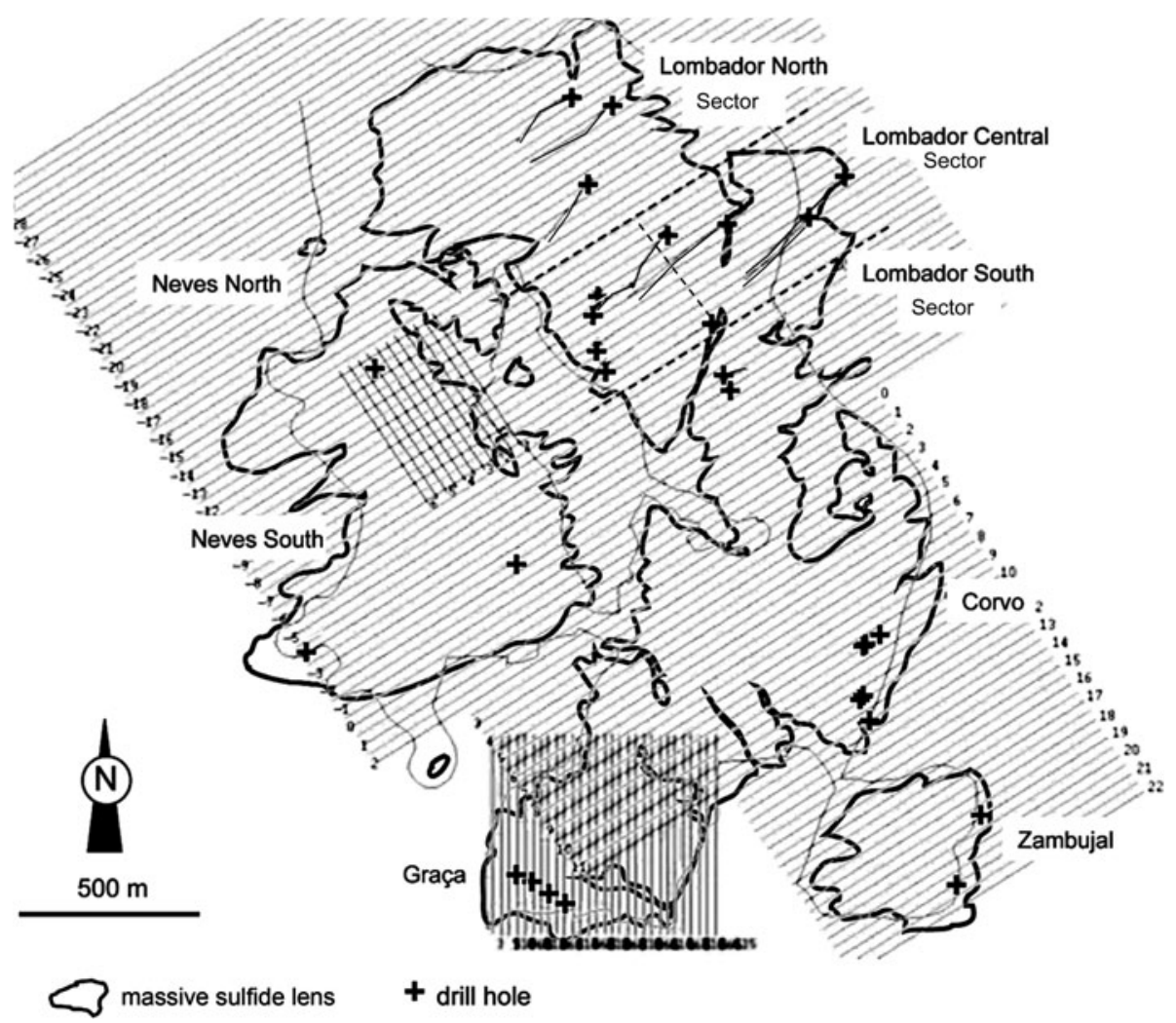

FIG. 2. Locations of the drill holes selected for the present study.

results, the MDL adopted for each element was always the highest value reported in Table 1 .

High-resolution images by means of secondary electrons or back-scattered electrons, and semiquantitative X-ray microanalysis by means of energy-dispersive spectrometry were performed at UT on a set of 14 representative ore samples. The equipment used was a JEOL 6610LV scanning electron microscope (SEM), equipped with an EDS Oxford silicon drift detector system capable of high count rates and good energy resolution, and an Oxford INCA data acquisition software application. The use of this technique was directed, in particular, at the acquisition of high-resolution images of Inand Se-bearing mineral grains. After carbon coating, the acceleration voltage was set at $15 \mathrm{kV}$, and the automatic peak identification option selected to minimize spurious peaks by adjusting the auto ID sensitivity.

The overall characterization and interpretation of the In and Se spatial distribution, metal grades and element-element correlations were based on data provided by, or collected in collaboration with, the mine geology department of Somincor-Lundin Mining. The Somincor-Lundin mining wholerock chemical database available includes almost half a million of analyses $(n=419,386)$ performed at the accredited chemical laboratory of the company (AAS, XRF, ICP), on 1-2 m-wide intervals of ore drill cores, and was managed by mining software tools (Leapfrog ${ }^{\circledR}$ and Vulcan $\AA$ $3 \mathrm{D})$ that provided $3 \mathrm{D}$ models of the orebodies, ore-type distribution maps and cross sections, metal grades, and correlation matrix tables for a large set of major and minor ore elements (with a confidence level of $95 \%$ ).

\section{Results}

\section{Ore mineralogy and textures}

Detailed petrographic inspection of the ore mineral assemblages, coupled with extensive EPMA and SEM data revealed a widely varied mineralogy 
TABLE 1. Electron microprobe minimum detection limits (MDL), X-ray lines, crystals and peak counting times for In, Se and other elements given by the two probes used in this study.

\begin{tabular}{|c|c|c|c|c|c|c|c|c|}
\hline & \multicolumn{4}{|c|}{ EPMA UT } & \multicolumn{4}{|c|}{ EPMA HIF } \\
\hline & MDL (ppm) & Line & Crystal & Peak counting times (s) & MDL (ppm) & Line & Crystal & Peak counting time (s) \\
\hline $\mathrm{S}$ & 190 & $K \alpha$ & PET & 20 & 60 & $K \alpha$ & PETH & 20 \\
\hline $\mathrm{Fe}$ & 210 & $K \alpha$ & $\mathrm{LiF}$ & 20 & 100 & $K \alpha$ & LIFH & 30 \\
\hline $\mathrm{Cu}$ & 310 & $K \alpha$ & $\mathrm{LiF}$ & 20 & 180 & $K \alpha$ & LIFH & 30 \\
\hline $\mathrm{Zn}$ & 170 & $K \alpha$ & $\mathrm{LiF}$ & 60 & 160 & $K \alpha$ & LIFH & 40 \\
\hline $\mathrm{Pb}$ & 890 & $M \alpha$ & PET & 20 & 200 & $M \alpha$ & PETH & 40 \\
\hline As & 320 & $K \alpha$ & $\mathrm{LiF}$ & 60 & 150 & $L \alpha$ & TAP & 60 \\
\hline $\mathrm{Ni}$ & 250 & $K \alpha$ & $\mathrm{LiF}$ & 20 & 120 & $K \alpha$ & LIFH & 40 \\
\hline $\mathrm{Sb}$ & 190 & $L \alpha$ & PET & 60 & 270 & $L \beta$ & PETH & 40 \\
\hline Sn & 330 & $L \alpha$ & PET & 20 & 160 & $L \alpha$ & PETL & 40 \\
\hline Co & 70 & $K \alpha$ & $\mathrm{LiF}$ & 60 & 330 & $K \alpha$ & LIFH & 10 \\
\hline $\mathrm{Mn}$ & 90 & $L \alpha$ & PET & 20 & & & & \\
\hline $\mathrm{Hg}$ & 910 & $L \alpha$ & $\mathrm{LiF}$ & 60 & 310 & $M \alpha$ & PETH & 40 \\
\hline $\mathrm{Ag}$ & 300 & $L \alpha$ & PET & 60 & 170 & $L \alpha$ & PETL & 40 \\
\hline $\mathrm{Au}$ & 880 & $L \alpha$ & $\mathrm{LiF}$ & 40 & & & & \\
\hline $\mathrm{Bi}$ & 970 & $L \alpha$ & $\mathrm{LiF}$ & 60 & 250 & $M \alpha$ & PETH & 40 \\
\hline $\mathrm{Ge}$ & 30 & $K \alpha$ & $\mathrm{LiF}$ & 60 & 110 & $L \alpha$ & TAP & 60 \\
\hline $\mathrm{Se}$ & 380 & $K \alpha$ & $\mathrm{LiF}$ & 60 & 180 & $L \alpha$ & TAP & 60 \\
\hline In & 180 & $L \alpha$ & PET & 60 & 110 & $L \alpha$ & PETL & 80 \\
\hline $\mathrm{Cd}$ & 340 & $L \alpha$ & PET & 60 & 150 & $L \alpha$ & PETL & 40 \\
\hline $\mathrm{Tl}$ & 590 & $L \alpha$ & $\mathrm{LiF}$ & 60 & & & & \\
\hline $\mathrm{Te}$ & 1400 & $L \alpha$ & $\mathrm{LiF}$ & 120 & & & & \\
\hline
\end{tabular}

(Table 2; Figs 3 and 4). Although the different orebodies and ore types studied present essentially the same major ore minerals, their relative proportions in the various ore types are highly variable, and some mineral phases were only found in particular ore types and ore settings. Pyrite, sphalerite, chalcopyrite and galena represent the main ore minerals, whereas arsenopyrite and tetrahedrite constitute the most common accessory minerals, together with variable amounts of tennantite, stannite, kesterite, ferrokesterite, bournonite, boulangerite, cassiterite, pyrrhotite, cobaltite, glaucodot, cosalite, löllingite, naumannite, idaite, mawsonite, carrollite, gustavite and native bismuth (see also Pinto et al., 1997, 2014; Gaspar, 2002). Roquesite and gold/electrum were seldom identified. It was also possible to positively identify fine-grained intergrowths of complex Se-bearing $\mathrm{Pb}-\mathrm{Bi}$-sulfosalts that seem to correspond to the compositions of junoite, cannizarrite and wittite, as well as unnamed complex Bi-Se and Se-bearing $\mathrm{Pb}-\mathrm{Bi}$ phases containing $>20 \mathrm{wt} . \%$ Se, and very fine-grained (usually $<2 \mu \mathrm{m}$ ) In-bearing phases, tentatively classified as sakuraiite and/or a sakuraiite-roquesite intermediate phase. The gangue mineralogy consists mainly of quartz, chlorite, sericite and siderite (mainly sideroplesite), together with minor amounts of donbassite, rutile and florencite.

Most primary textures and textural relationships between the sulfide ore minerals were obscured either by hydrothermal re-working processes (e.g. zone refining), and/or by subsequent tectonometamorphic overprinting effects (e.g. brecciation, ductile deformation, recrystallization) (Figs 3 and 4). Nevertheless, some early hydrothermal assemblages and textures are still preserved. Commonly, the textural signatures of the early stages of oreformation are better preserved in the lowtemperature ore types (ME, MP, MZ and MZP), and include partly recrystallized pyritic colloform overgrowths (often polymineralic), framboidal pyrite and porous pyrite aggregates with sphalerite and galena dispersed nuclei, as well as brecciated to banded semi-massive ore layers intergrown with siderite, and/or with interbedded siderite-rich layers, which indicate direct exhalation on the seafloor, distal deposition and redepositional processes (Fig. 3). Many minerals associated with the early stages of ore generation (e.g. pyrite, 
TABLE 2. Summary table of the mineralogy identified in the major ore types of the Neves-Corvo deposit.

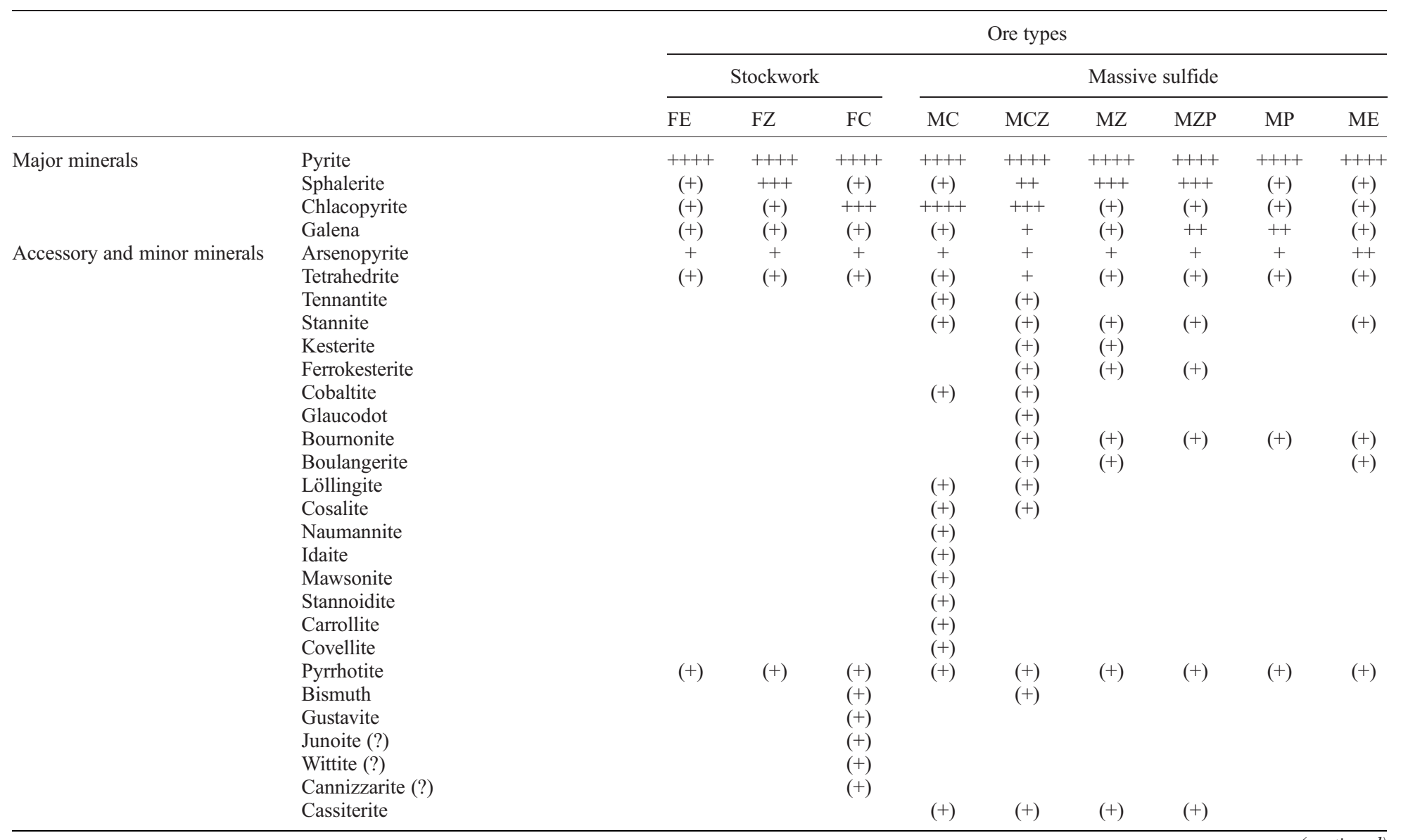


TABle 2. (contd.)

\begin{tabular}{|c|c|c|c|c|c|c|c|c|c|c|}
\hline & & \multicolumn{9}{|c|}{ Ore types } \\
\hline & & \multicolumn{3}{|c|}{ Stockwork } & \multicolumn{6}{|c|}{ Massive sulfide } \\
\hline & & $\mathrm{FE}$ & $\mathrm{FZ}$ & $\mathrm{FC}$ & $\mathrm{MC}$ & $\mathrm{MCZ}$ & $\mathrm{MZ}$ & MZP & MP & ME \\
\hline \multirow[t]{4}{*}{ Trace minerals } & Gold/electrum & & & $(+)$ & & & & & & \\
\hline & Roquesite & & & & $(+)$ & $(+)$ & & & & $(+)$ \\
\hline & Unknown $\mathrm{Bi}-\mathrm{Se}$ and $\mathrm{Pb}-\mathrm{Bi}-\mathrm{Se}$ phases & & & & & $(+)$ & & & & \\
\hline & Sakuraiite or roquesite-sakuraiite phase & & & $(+)$ & & $(+)$ & & & & \\
\hline \multirow[t]{10}{*}{ Ore-related gangue minerals } & Quartz & ++++ & +++ & +++ & $(+)$ & $(+)$ & $(+)$ & $(+)$ & $(+)$ & $(+)$ \\
\hline & Ripidolite & + & ++++ & ++++ & & $(+)$ & $(+)$ & & & \\
\hline & Brunsvigite & $(+)$ & $(+)$ & $(+)$ & & & & & & \\
\hline & Donbassite & $(+)$ & $(+)$ & $(+)$ & & & & & & \\
\hline & Sericite & ++ & ++ & + & & & & & & \\
\hline & Siderite & +++ & +++ & +++ & & + & + & + & & \\
\hline & Ankerite & & + & & & & & & & \\
\hline & Dolomite & & $(+)$ & & & & & & & \\
\hline & Rutile & $(+)$ & $(+)$ & $(+)$ & & & $(+)$ & & & \\
\hline & Florencite & $(+)$ & $(+)$ & $(+)$ & & & & & & \\
\hline
\end{tabular}

FE - barren stockwork; FZ - zinc stockwork; FC - copper stockwork; MC - massive copper ore, MCZ - massive copper-zinc ore; MZ - massive zinc ore; MZP - massive zinc-lead ore; MP - massive lead ore; ME - massive barren sulfides. Relative abundances (symbols): $(+): \leq 1 \% ;+: 1-10 \% ;++: 10-20 \% ;+++: 20-50 \%$; $++++: \geq 50 \%$. 


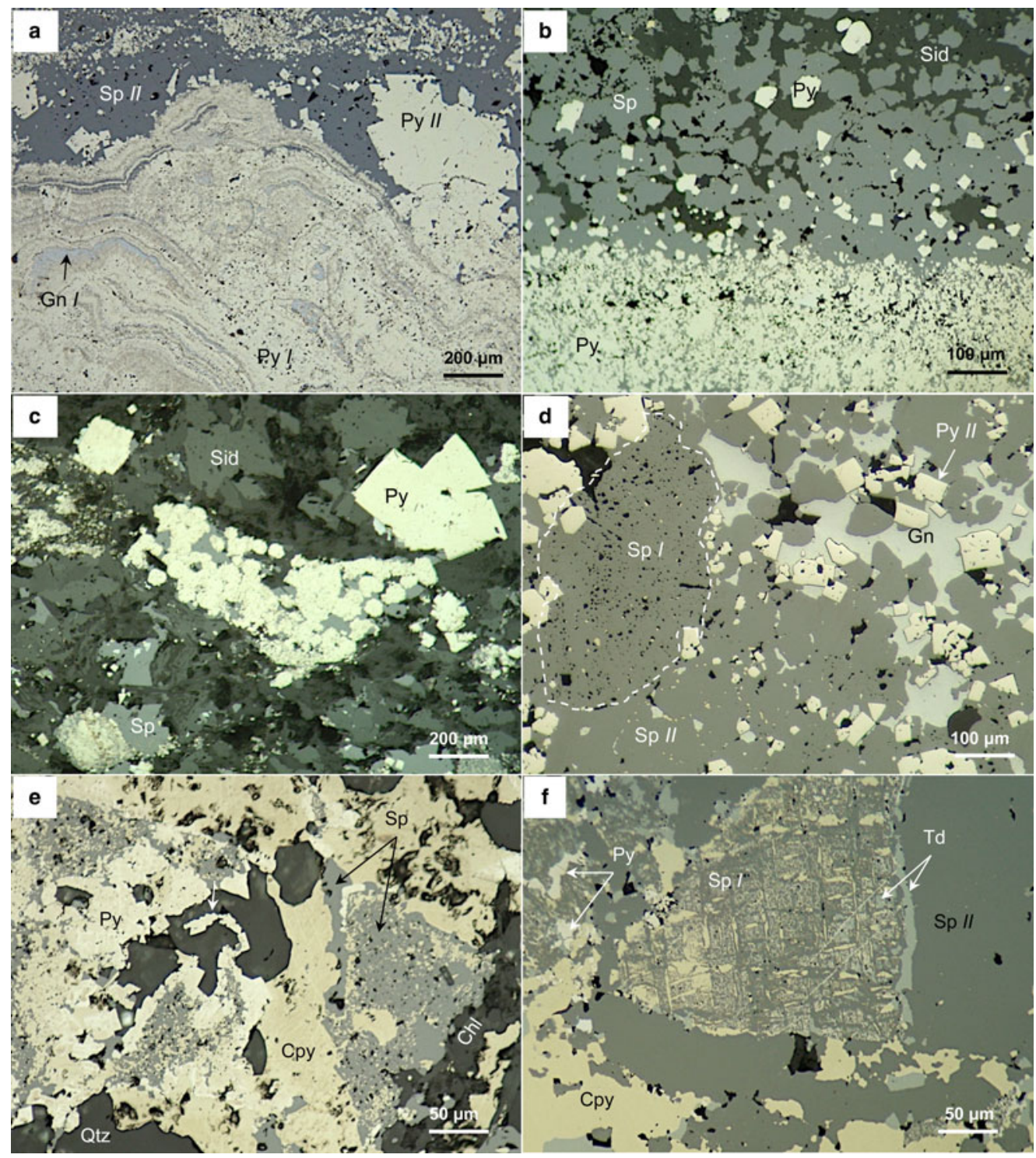

FIG. 3. Photomicrographs depicting textural features and ore minerals identified related to early stage ore-forming processes and subsequent replacement. (a) Remnants of partly recrystallized early-generation pyrite (Py $I$ ) colloform overgrowths filled by spahlerite ( $\mathrm{Sp} I)$ and galena $(\mathrm{Gn} I)$ involved with later-generation sphalerite $(\mathrm{Sp} I I)$ and pyrite (Py II). (b) Low-temperature, banded, zinc-rich ores intergrown with siderite-rich layers (Sid) indicating direct exhalation onto the seafloor. (c) Pyrite- and sphalerite-rich sulfide clasts within a siderite-rich groundmass as a result of redepositional processes. $(d)$ Replacement of early generation sphalerite $(\mathrm{Sp} I)$ by a late generation sphalerite $(\mathrm{Sp} I I)$ in the zinc-rich ores which is often annealed and intergrown with galena. $(e, f)$ Replacement of sphalerite (Sp) and pyrite (Py) crystals by chalcopyrite (Cpy) and tetrahedrite (Td).

arsenopyrite) are variably preserved in sphaleriteand chalcopyrite-rich domains, whereas other ore minerals formed during subsequent tectonometamorphic stages are found either filling veins, veinlets and/or fractures in pre-existing mineral phases (e.g. chalcopyrite, sphalerite, tetrahedrite, galena), or as very fine-grained blebs along the boundaries of recrystallized and annealed 


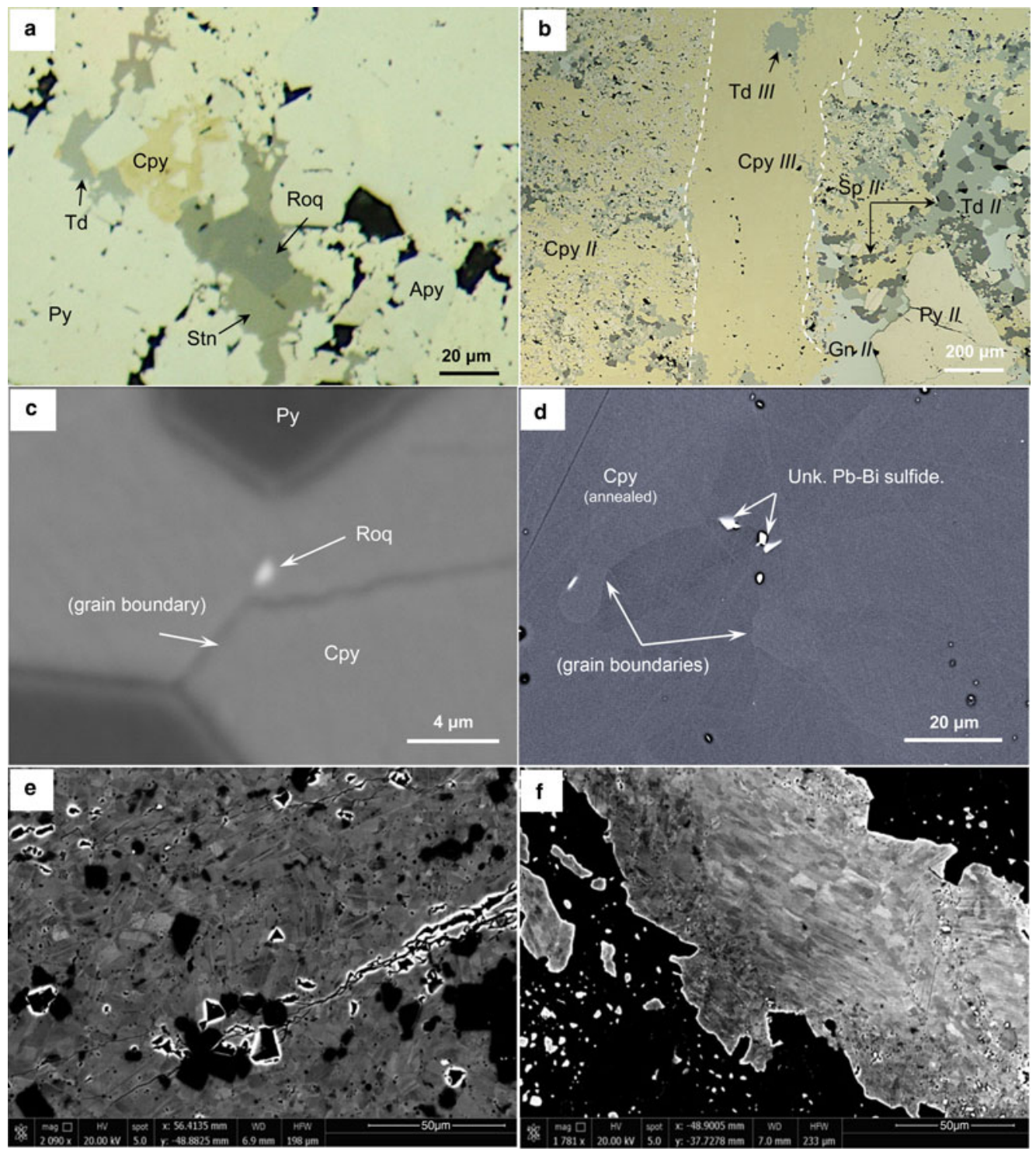

FIG. 4. Photomicrographs and high-resolution SEM images depicting textural features and ore minerals identified related to replacement and late, tectonometamorphic deformation. (a) Roquesite (Roq) intergrown with stannite (Stn). (b) Late, postmetallogenetic and tectonometamorphism-related generation chalcopyrite (Cpy III) and tetrahedrite (Td III) veinlet crosscutting a metallogenesis-related chalcopyrite (Cpy II) groundmass that replaces pyrite (Py II), sphalerite (Sp II) and tetrahedrite (Td II) and galena ( $\mathrm{Gn} I I)$. ( $c, d)$ Occurrence of indium- and selenium-rich phases along chalcopyrite grain boundaries due to tectonometamorphic overprinting effects. (e) High-resolution back-scattered image depicting recrystallized sphalerite crystals within a massive zinc ore due to late tectonometamorphic deformation. $(f)$ High-resolution

back-scattered image depicting recrystallized chalcopyrite crystals due to late tectonometamorphic deformation.

chalcopyrite and/or chalcopyrite-sphalerite grains (e.g. stannite, roquesite and unnamed Se-bearing $\mathrm{Pb}-\mathrm{Bi}$ phases; Fig. 4). Nevertheless, in situ replacement of one or more minerals by another is fairly common. Interstitial filling of pyrite by sphalerite, galena, chalcopyrite and, to a lesser extent, tetrahedrite is ubiquitous, and pyrite and arsenopyrite are most frequently replaced by 
sphalerite, galena and/or chalcopyrite. Chalcopyrite replaces sphalerite in the $\mathrm{Cu}-\mathrm{Zn}$ (MCZ) ores (Fig. 3). Textures produced as a result of brittle and ductile tectonic deformation and tectonometamorphic recrystallization are very common throughout the different ore types and orebodies, and strongly influenced the distribution of the ore mineral assemblages and mineral associations, as well as the chemical composition of most of the major ore sulfides and the distribution of In and Se in the Neves-Corvo ores (Fig. 4). Very significant recrystallization and annealing effects related to tectonometamorphic overprinting have promoted: (1) the precipitation of phases held in solid solution and their migration into the host grain boundaries; (2) the development of non-equigranular mosaics of crystals with $\sim 120^{\circ}$ interfacial angles, in particular within the sphalerite- and chalcopyrite-dominated layers; and (3) the chemical re-equilibration of the ore sulfide assemblages in general. At least three major generations of the main ore minerals could be distinguished on the basis of textural interpretation of the complex succession of syn- and postmineralization processes identified (Figs 3 and 4).

\section{Indium and selenium distribution in the Neves- Corvo deposit}

The distributions of In and Se in the Neves-Corvo deposit are complex, and reflect the combined effects of ore-forming processes, including the redistribution associated with long-lasting hydrothermal reworking and zone-refining, and the redistribution and concentration processes related to late tectonometamorphic remobilization and orerecrystallization overprint.

Based on the observed metal correlations and estimated ore grades provided by the Leapfrog ${ }^{\circledR}$ and Vulcan ${ }^{\circledR} 3 \mathrm{D}$ mining software, at the deposit scale both $\mathrm{In}$ and Se correlate positively with $\mathrm{Cu}$ $(r=0.44$ and $r=0.55$, respectively; Table 3 ), and high grades of In and Se are found mainly in the $\mathrm{Cu}$ (FC, MC, RC) and Cu-Zn (MCZ) ore types (Fig. 5). Mine-block estimation models indicate In and Se average grades of 58 and $63 \mathrm{ppm}$, respectively, for the deposit as a whole. The $\mathrm{Cu}$-rich ores have average grades of $64 \mathrm{ppm}$ In and $71 \mathrm{ppm}$ Se. Locally, the In grade may reach $>640 \mathrm{ppm}$ in the $\mathrm{Cu}$ stockwork ores (FC), and $>2000 \mathrm{ppm}$ in the massive $\mathrm{Cu}(\mathrm{MC})$ and $\mathrm{Cu}-\mathrm{Zn}(\mathrm{MCZ})$ ore types, whereas Se grade can exceed $2450 \mathrm{ppm}$ locally in massive $\mathrm{Cu}$ ores. However, not all $\mathrm{Cu}$-rich ores are necessarily rich in In and/or Se.

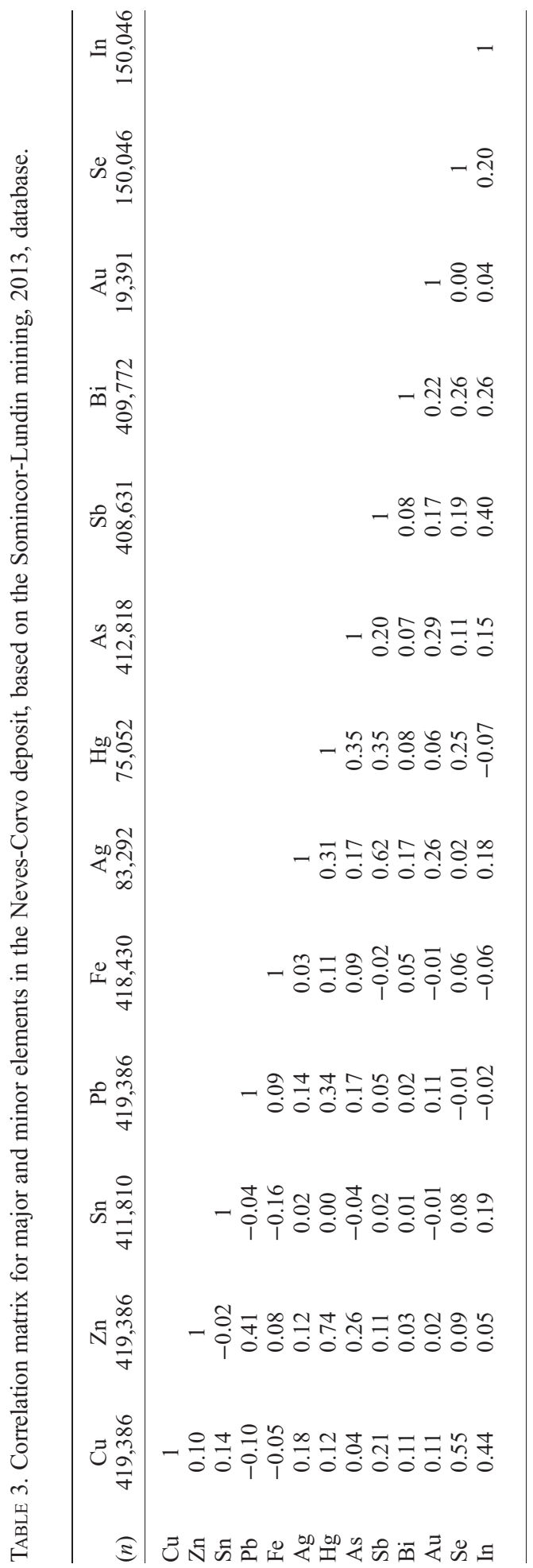




\section{J. R. S. CARVALHO ETAL.}

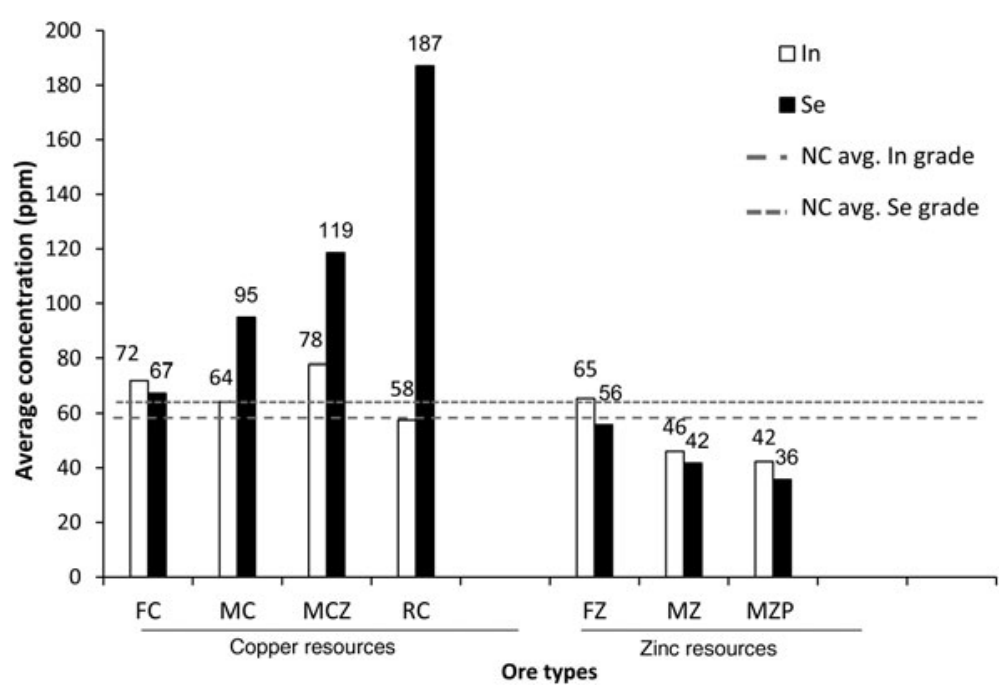

FIG. 5. Indium and Se average grades in the different stockwork and massive sulfide ore types mined at the Neves Corvo deposit (after Somincor-Lundin Mining, 2013, database). The dashed lines represent the average In (58 ppm) and Se (63 ppm) grades in the deposit. FZ - zinc stockwork ore; FC - copper stockwork ore; MC - massive copper ore; MCZ massive copper-zinc ore; MZ - massive zinc ore; MZP - massive zinc-lead ore; RC ore type (copper 'rubané' ore) corresponds to a copper stockwork ore (FC) emplaced tectonically into a hanging-wall position (Oliveira et al., 2004; Relvas et al., 2006a); NC avg. - In and Se average grades in the Neves Corvo deposit.

No correlation was found between In or Se with either $\mathrm{Zn}$ or $\mathrm{Pb}$ at the deposit scale $(r=0.05$ and $r=0.09$, respectively, for $\mathrm{Zn}$, and $r=-0.02$ and $r=-0.01$, respectively, for $\mathrm{Pb}$; Table 3). Nevertheless, significant In and Se grades (up to 400 and $8000 \mathrm{ppm}$, respectively) have been found locally in some $\mathrm{Zn}$ and $\mathrm{Zn}-\mathrm{Pb}$ ores, in particular in close spatial dependence of fault/fracture zones (Pinto et al., 2014; Carvalho et al., 2015). On average, the In and Se grades in the zinc-rich ores (FZ, MZ, MZP) are $\sim 45$ and $\sim 37 \mathrm{ppm}$, respectively. Similar to the $\mathrm{Cu}$ ores, the In and/or $\mathrm{Se}$ contents in the $\mathrm{Zn}$-rich ores are not homogeneous.

In addition to a slightly positive correlation with $\mathrm{Se}$ $(r=0.20)$, In also displays a small positive correlation $(r=\leq 0.40)$ with other elements, such as $\mathrm{Sb}, \mathrm{Sn}, \mathrm{As}$ and $\mathrm{Bi}$ (Table 3 ). Selenium displays a slightly positive correlation $(r \leq 0.26)$ with $\mathrm{Hg}, \mathrm{As}, \mathrm{Sb}$ and $\mathrm{Bi}$.

Tables 4 and 5 show the correlation coefficients between the main ore metals, In and Se, when taken as a function of the various ore types, and the various orebodies, respectively. Overall, the correlations between In and $\mathrm{Zn}$ are low, reaching its maximum value for the massive $\mathrm{Zn}$ ore type (MZ; $r=0.30$ ). Once again, both In and Se consistently show higher correlation coefficients with $\mathrm{Cu}$ than with the remaining elements, in particular in the
$\mathrm{Cu}$-rich ores types and in the $\mathrm{Cu}$-rich orebodies (Table 6). The only exception is the Zambujal orebody, where both In and especially Se depict a slight but unexpected positive correlation with $\mathrm{Zn}$ $(r=0.17$ and $r=0.42$, respectively). This reflects the strong tectonic deformation undergone by this particular orebody, which is responsible for important high-grade $\mathrm{Cu}$ ore shoots resulting from significant secondary $\mathrm{Cu}$ remobilization, and accounted for re-distribution and re-concentration of trace elements, including In and Se. In fact, the complex geometric intercalations and variations of ore types seen both vertically and laterally throughout the Zambujal orebody are due to a succession of tectonically stacked massive sulfide lenses folded to the west (low-angle Hercynian thrust tectonics).

The overall correlation between In and Se with $\mathrm{Cu}$ at several scales, as well as their higher abundances in $\mathrm{Cu}$-rich ores, are strongly indicative of a genetic connection between the three elements. Moreover, by analogy with present-day submarine hydrothermal systems (e.g. Hannington et al., 1986; Auclair and Fouquet, 1987; Herzig et al., 1998; Schwarz-Shampera, 2000), the abundance and distribution of In and Se in the Neves-Corvo orebodies suggest that, at the scale of the whole hydrothermal field, the various orebodies represent 
TABLE 4. Correlation matrix between In and Se with major and minor ore metals in the various ore types at the Neves-Corvo deposit, based on the SomincorLundin mining, 2013, chemical database.

\begin{tabular}{|c|c|c|c|c|c|c|c|c|c|c|c|c|c|c|}
\hline & & & $\mathrm{Cu}$ & $\mathrm{Zn}$ & Sn & $\mathrm{Pb}$ & $\mathrm{Fe}$ & $\mathrm{Ag}$ & $\mathrm{Hg}$ & As & $\mathrm{Sb}$ & $\mathrm{Bi}$ & $\mathrm{Au}$ & $\mathrm{Se}$ \\
\hline \multirow[t]{9}{*}{ Zinc-rich ore types } & $(n)$ & 4711 & & & & & & & & & & & & \\
\hline & FZ & $\mathrm{Se}$ & 0.45 & -0.07 & -0.04 & 0.05 & 0.12 & 0.00 & 0.00 & 0.19 & -0.02 & 0.02 & 0.00 & 1 \\
\hline & & In & 0.34 & 0.19 & 0.09 & 0.07 & -0.18 & 0.00 & 0.00 & 0.13 & 0.05 & 0.15 & 0.00 & 0.20 \\
\hline & $(n)$ & 19,087 & & & & & & & & & & & & \\
\hline & MZ & $\mathrm{Se}$ & 0.05 & -0.13 & -0.05 & 0.08 & 0.07 & -0.16 & 0.09 & -0.14 & -0.18 & -0.08 & -0.04 & 1 \\
\hline & & In & 0.04 & 0.30 & 0.00 & -0.02 & -0.27 & 0.12 & -0.02 & 0.15 & 0.00 & 0.08 & -0.09 & -0.03 \\
\hline & $(n)$ & 9540 & & & & & & & & & & & & \\
\hline & MZP & $\mathrm{Se}$ & -0.04 & -0.08 & 0.01 & -0.02 & 0.05 & -0.14 & 0.13 & -0.05 & -0.13 & -0.06 & -0.02 & 1 \\
\hline & & In & 0.10 & 0.23 & -0.05 & 0.03 & -0.21 & 0.14 & -0.10 & 0.11 & 0.03 & 0.04 & -0.27 & -0.06 \\
\hline \multirow[t]{9}{*}{ Copper-rich ore types } & $(n)$ & 45,012 & & & & & & & & & & & & \\
\hline & $\mathrm{FC}$ & $\mathrm{Se}$ & 0.66 & 0.18 & 0.17 & 0.02 & 0.06 & 0.17 & 0.29 & 0.05 & 0.13 & 0.29 & 0.26 & 1 \\
\hline & & In & 0.33 & 0.14 & 0.15 & 0.05 & 0.05 & 0.33 & 0.18 & 0.14 & 0.25 & 0.28 & 0.25 & 0.17 \\
\hline & $(n)$ & 21,729 & & & & & & & & & & & & \\
\hline & MC & $\mathrm{Se}$ & 0.49 & 0.10 & 0.04 & -0.02 & -0.18 & -0.02 & 0.34 & -0.03 & 0.14 & 0.23 & -0.22 & 1 \\
\hline & & In & 0.45 & 0.15 & 0.22 & 0.00 & -0.22 & 0.18 & 0.21 & 0.16 & 0.50 & 0.17 & 0.07 & 0.21 \\
\hline & $(n)$ & 8344 & & & & & & & & & & & & \\
\hline & MCZ & $\mathrm{Se}$ & 0.72 & 0.42 & -0.07 & -0.26 & -0.59 & -0.07 & 0.71 & 0.34 & 0.26 & 0.32 & -0.31 & 1 \\
\hline & & In & 0.42 & 0.16 & 0.33 & -0.17 & -0.34 & 0.33 & 0.10 & 0.16 & 0.48 & 0.21 & 0.03 & 0.17 \\
\hline \multirow[t]{9}{*}{ Barren and lead ores } & $(n)$ & 20,389 & & & & & & & & & & & & \\
\hline & $\mathrm{FE}$ & $\mathrm{Se}$ & 0.11 & 0.07 & -0.01 & 0.09 & 0.05 & 0.17 & 0.32 & 0.04 & 0.07 & 0.22 & 0.02 & 1.00 \\
\hline & & In & 0.10 & -0.06 & 0.01 & -0.03 & -0.10 & -0.03 & -0.11 & 0.05 & 0.01 & 0.04 & 0.06 & 0.05 \\
\hline & $(n)$ & 15,235 & & & & & & & & & & & & \\
\hline & ME & $\mathrm{Se}$ & 0.02 & 0.00 & -0.05 & 0.21 & 0.06 & -0.02 & -0.01 & -0.14 & -0.17 & -0.09 & -0.16 & 1.00 \\
\hline & & In & 0.08 & -0.01 & 0.03 & -0.05 & -0.23 & 0.06 & -0.03 & 0.14 & 0.04 & 0.04 & -0.03 & -0.01 \\
\hline & $(n)$ & 580 & & & & & & & & & & & & \\
\hline & MP & $\mathrm{Se}$ & -0.12 & -0.03 & 0.08 & -0.16 & 0.11 & 0.63 & 0.16 & -0.10 & -0.17 & -0.15 & 0.18 & 1.00 \\
\hline & & In & 0.07 & 0.00 & 0.04 & -0.02 & -0.10 & 0.53 & 0.36 & 0.12 & 0.07 & -0.01 & 0.06 & 0.00 \\
\hline
\end{tabular}




\section{J.R. S. CARVALHO ETAL.}

TABLE 5. Correlation matrix between In and Se, and a number of other ore metals in the five orebodies currently exploited at the Neves-Corvo mine, based on the Somincor-Lundin mining, 2013, database.

\begin{tabular}{lcccccccccccc}
\hline & & $\mathrm{Cu}$ & $\mathrm{Zn}$ & $\mathrm{Sn}$ & $\mathrm{Pb}$ & $\mathrm{Fe}$ & $\mathrm{Ag}$ & $\mathrm{Hg}$ & $\mathrm{As}$ & $\mathrm{Sb}$ & $\mathrm{Bi}$ & $\mathrm{Au}$ \\
\hline Corvo $(n=39,099)$ & $\mathrm{Se}$ & 0.74 & -0.01 & 0.18 & -0.02 & 0.00 & 0.15 & -0.05 & 0.14 & 0.20 & 0.42 & 0.04 \\
& $\mathrm{In}$ & 0.38 & 0.10 & 0.13 & -0.01 & -0.05 & 0.22 & 0.01 & 0.12 & 0.39 & 0.23 & 0.11 \\
Neves $(n=51,649)$ & $\mathrm{Se}$ & 0.56 & 0.06 & 0.05 & 0.03 & 0.14 & 0.11 & 0.05 & 0.06 & 0.12 & 0.26 & -0.01 \\
& $\mathrm{In}$ & 0.68 & 0.00 & 0.31 & 0.00 & -0.02 & 0.26 & 0.03 & 0.12 & 0.36 & 0.25 & 0.05 \\
Graça $(n=7459)$ & $\mathrm{Se}$ & 0.80 & -0.06 & 0.48 & -0.14 & -0.09 & 0.05 & -0.02 & 0.02 & 0.38 & 0.34 & 0.60 \\
& $\mathrm{In}$ & 0.56 & 0.13 & 0.53 & -0.06 & -0.11 & 0.22 & 0.21 & 0.20 & 0.63 & 0.31 & 0.51 \\
Zambujal $(n=22,315)$ & $\mathrm{Se}$ & 0.58 & 0.42 & -0.03 & 0.10 & 0.17 & 0.04 & 0.30 & 0.31 & 0.25 & 0.29 & -0.02 \\
& $\mathrm{In}$ & 0.47 & 0.17 & 0.02 & -0.04 & -0.13 & 0.14 & -0.03 & 0.22 & 0.56 & 0.23 & 0.03 \\
Lombador $(n=28,624)$ & $\mathrm{Se}$ & 0.38 & -0.05 & 0.06 & -0.01 & 0.03 & 0.06 & -0.05 & 0.04 & 0.22 & 0.40 & 0.19 \\
& $\mathrm{In}$ & 0.46 & 0.01 & 0.08 & 0.00 & -0.09 & 0.16 & -0.13 & 0.08 & 0.50 & 0.40 & 0.21 \\
& & & & & & & & & & & & \\
\hline
\end{tabular}

different stages of an evolving ore-forming system. It is shown below that other factors and overprinting effects become relevant at smaller scales.

\section{Ore-formation vs. tectonometamorphic overprint at the Lombador orebody}

\section{Primary control}

The Zn-rich Lombador orebody depicts the lowest In and Se grades of the whole deposit (Table 6). The metal distribution maps in this orebody are particularly clear in indicating that higher In and Se grades correlate with the ore zones that are richer in $\mathrm{Cu}$, in the central-W sector of the orebody, where the innermost zone of the feeder system occurs, and where the more chalcopyrite-rich ores (FC, MC, MCZ) dominate (Fig. 6; Carvalho et al., 2013, 2015; Carvalho, 2016). The distribution of $\mathrm{Cu}$, In and Se at the Lombador orebody (as well as Ag, Bi and, to a lesser extent, $\mathrm{Au}$ ) is associated closely with a major NNW-SSE-trending, sub-vertical fault zone (Fig. 6) that denounces a net tectonic control over the focusing of the high-temperature $\mathrm{Cu}$-rich hydrothermal fluids. Hence, this metal association is particularly well represented in the copper stockwork ore samples (FC). Conversely, in the $\mathrm{Zn}$-rich ore zones, both In and Se display lower concentrations and broader distribution patterns. Therefore, at the scale of the Lombador orebody, it is again very clear that most, or at least a significant part, of the In and Se must have been introduced with $\mathrm{Cu}$ into the mineralizing system, probably sharing a common source and common histories of transport and precipitation from $\mathrm{Cu}$-rich mineralizing fluids. Nevertheless, the present data do not preclude other possible metal sources for these metals, namely leaching of the footwall sequence.

\section{Tectonometamorphic overprint}

In addition to the primary control over In and Se distributions in the Lombador orebody, there is ample evidence for prominent In- and Se-enrichment and re-distribution due to tectonometamorphic remobilization. Figure 7 shows

TABLE 6. Size, selected major and minor ore elements concentrations, and copper ratio $(100 * \mathrm{Cu} /(\mathrm{Cu} / \mathrm{Zn}))$ for the five orebodies currently exploited at the Neves-Corvo deposit, based on the Somincor-Lundin mining, 2013, database.

\begin{tabular}{lccccccccc}
\hline Orebody & Tonnage (Mt) & $\mathrm{Cu}(\%)$ & $\mathrm{Zn} \mathrm{( \% )}$ & $\mathrm{Pb}(\%)$ & $\mathrm{Sn}(\%)$ & $\mathrm{Ag}(\mathrm{ppm})$ & $\mathrm{Se}(\mathrm{ppm})$ & $\mathrm{In}(\mathrm{ppm})$ & $\mathrm{Cu}$ ratio \\
\hline Lombador & 106.2 & 0.78 & 4.42 & 1.16 & 0.04 & 53.34 & 36 & 47 & 15 \\
Corvo & 50.6 & 5.61 & 2.07 & 0.42 & 0.28 & 49.84 & 103 & 67 & 73 \\
Neves & 63.2 & 1.93 & 2.61 & 0.59 & 0.14 & 59.59 & 47 & 65 & 43 \\
Graça & 11.3 & 5.61 & 3.72 & 0.44 & 0.31 & 61.42 & 75 & 72 & 60 \\
Zambujal & 14.7 & 2.30 & 2.52 & 0.49 & 0.04 & 35.09 & 154 & 63 & 48 \\
\hline
\end{tabular}




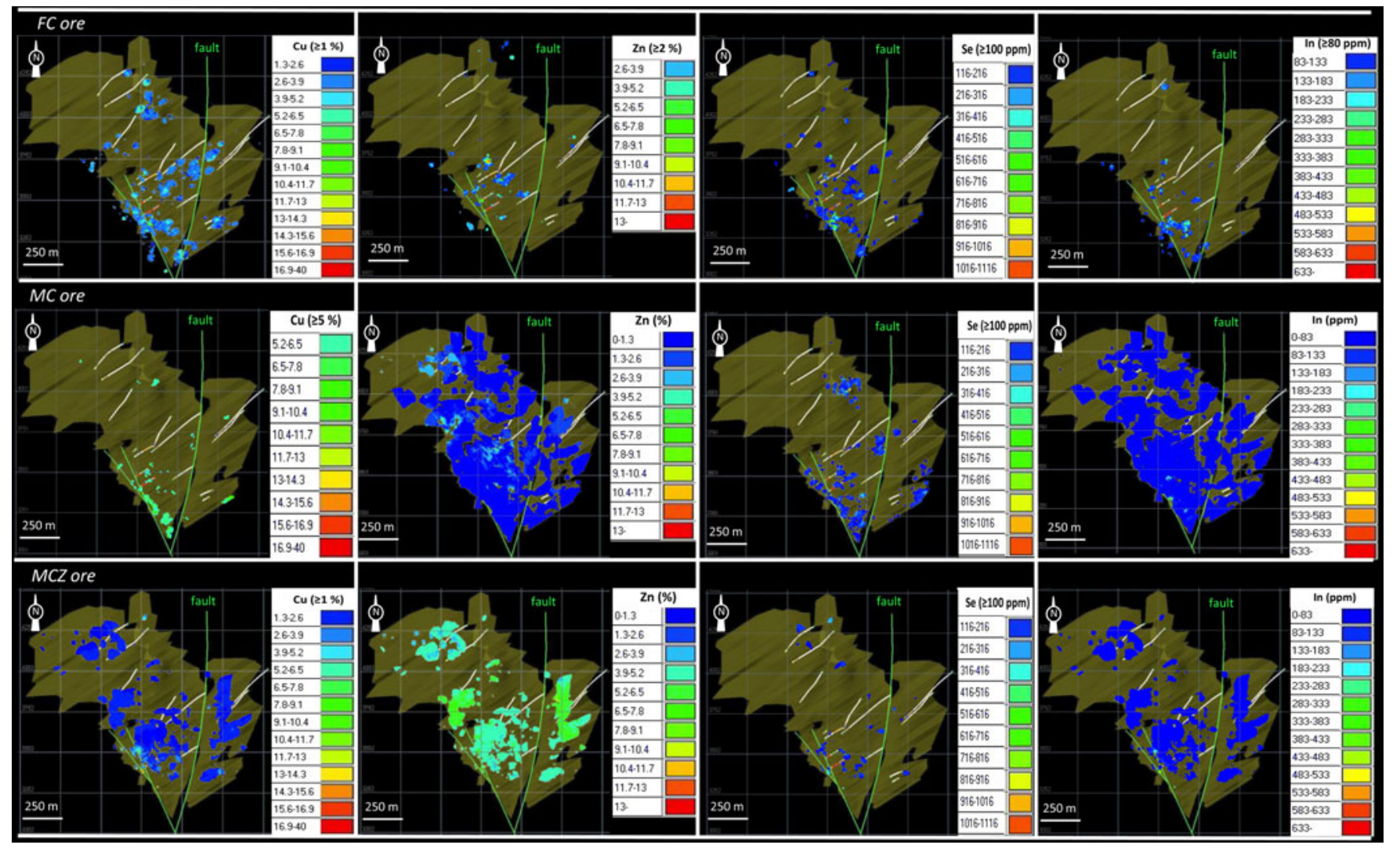

FIG. 6. Copper, Zn, Se and In distribution in four of the more represented ore types at the Lombador orebody: stockwork copper ore (FC), massive copper ore (MC), massive copper-zinc ore (MCZ) and massive zinc ore (MZ). Note the positive correlation between the high $\mathrm{Cu}$, In and Se grades around the NNW-SSE fault zone, and the poor, if any, correlation between Zn, In and Se at the Lombador orebody. Data from the Somincor-Lundin mining, 2013, database. 

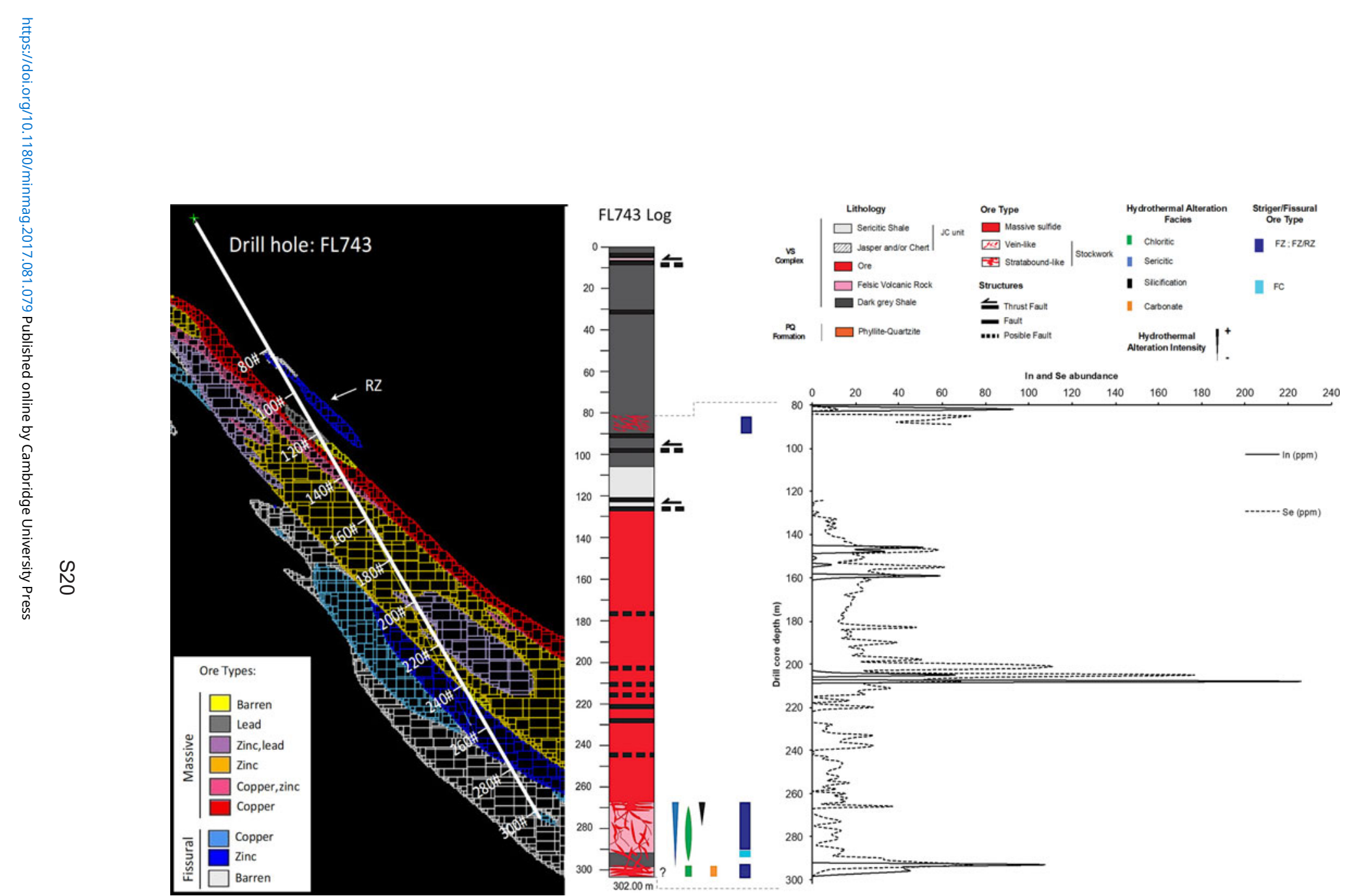

FIG. 7. Schematic representation of drill hole FL743 intersecting the Lombador orebody, together with its log features (ore types, alteration facies), and In and Se concentration profiles. Cross-section and metal grades are from the Somincor-Lundin mining, 2013, database. 
schematically the distribution profile of In and Se concentrations along a selected drill hole intersecting the Lombador orebody. Indium and $\mathrm{Se}$ concentrations were correlated with the various features recognized (hydrothermal alteration, ore types, faults, $\mathrm{Cu}, \mathrm{Zn}$ and $\mathrm{Pb}$ grades). It is very clear that high In and Se concentrations occur either associated with $\mathrm{Cu}$-rich intervals intersected (FC, $\mathrm{MC}$ and MCZ ore types), or are associated with shear zones occurring within the Zn-rich (MZ and MZP) ore zones. In the example presented, In and Se concentrations in the tectonically deformed MZ and MZP ore zones reach up to 226 and $176 \mathrm{ppm}$, respectively, which represent an enrichment of $\sim 500 \%$ and $200 \%$ relative to the average abundances (47 ppm In and $36 \mathrm{ppm} \mathrm{Se}$ ) in the Lombador orebody. The ore layers classified as $\mathrm{MC}$ and $\mathrm{MCZ}$ in a hanging-wall position correspond to intervals characterized by significant remobilization of chalcopyrite and, to a lesser extent, tetrahedrite, which accounted for pronounced secondary $\mathrm{Cu}$ enrichment that has been accompanied also by concomitant In and Se enrichment. In places, this late generation of remobilized chalcopyrite can represent up to $96 \%$ of the existing chalcopyrite.

Re-distribution and re-concentration of In and Se associated with tectonometamorphic deformation are processes of major importance for the actual distribution of these metals, not only in the Lombador orebody, but also throughout the whole Neves-Corvo deposit. Moreover, remobilization is thought to have also contributed to the local enrichment of other IPB deposits in In and/or Se. For example, the Barrigão deposit, a remobilization vein-type mineralization located $10 \mathrm{~km} \mathrm{SE}$ of Neves-Corvo, is reported to show significant In enrichment ( $c f$. Reiser et al., 2009).

\section{Indium and selenium mineral allocation}

Without detailed data on the modal compositions of individual ore samples, acquired by automated SEM-based mineralogy measurements, no quantitative assessments of In (and Se) deportment equivalent to those presented by Bachmann et al. (2017) were possible in the present study. Therefore, the following observations are qualitative only, being based on orders of magnitude of typical sulfide mineral abundances in the ores, as presented in Table 2, as well as concentrations in individual minerals determined by EPMA. The results are, nevertheless, instructive and may serve as important guides for future studies. We note that for In, our results are generally compatible with the quantitative results presented by Bachmann et al. (2017) for a more limited sample suite. For Se, no equivalent pre-existing data are available.

Tables 7 and 8 summarize the In and Se contents of the main ore minerals analysed, representing the various Neves-Corvo ore types. Although roquesite is the most In-rich ore sulfide found, the most abundant In-bearing sulfide minerals analysed are, by far, sphalerite and chalcopyrite given their overall abundance in the deposit (Table 2). Despite its high In content, stannite (together with ferrokesterite, kesterite, and tennantite) is probably only a minor contributor to the overall In budget in the Neves-Corvo deposit due to its overall abundance in the ores.

In contrast, $\mathrm{Se}$ is distributed much more widely over the different ore-forming minerals than In. The data in the present study might suggest that Se is mainly allocated in galena given its wide occurrence (Table 2). Nevertheless, arsenopyrite, chalcopyrite, pyrite and, to a lesser extent, tetrahedrite also constitute fairly important Se-bearing ore minerals due to their overall abundance in the deposit. Other Se-carriers include $\mathrm{Cu}$-Sn-sulfosalts such as stannite, kesterite, mawsonite and stannoidite, cobaltite, tennantite, naumannite and glaucodot, in order of decreasing abundance and likely importance as Se carriers. Despite the fairly high concentrations (up to $21.54 \mathrm{wt} . \% \mathrm{Se}$ ) in individual $\mathrm{Pb}-\mathrm{Bi}$ phases (see below), these make negligible contributions to the bulk Se abundance in the deposit due to their restricted occurrence (Table 2). Nonetheless, these complex phases may represent important $\mathrm{Se}$ carriers within some $\mathrm{Cu}$-rich ores.

\section{Chemical characteristics of the main In- and Se-bearing minerals}

Chemical re-equilibration imposed on the ore sulfides as a result of the late Hercynian tectonometamorphic overprint has resulted largely in localized homogenization of trace- and minorelement concentrations within the minerals. Individual sphalerite, chalcopyrite, galena, etc. grains are generally not compositionally zoned (e.g. Fig. $4 e, f$ ), and show relatively constant $\mathrm{In} / \mathrm{Se}$ concentrations within samples. Only the more refractory minerals, e.g. pyrite and arsenopyrite are often seen to preserve vestigial zonation patterns. These textural observations indicate that measured In and Se concentrations in most of the 
TABLE 7. Indium content (wt.\%) of the Neves-Corvo ore sulfides by means of EPMA and SEM-EDS analysis.

\begin{tabular}{|c|c|c|c|c|c|c|c|c|c|c|c|}
\hline & & \multicolumn{3}{|c|}{ Stockwork ore } & \multicolumn{6}{|c|}{ Massive sulfide ore } & \multirow[b]{2}{*}{ Avg. Comp. } \\
\hline & & $\mathrm{FE}$ & $\mathrm{FC}$ & FZ & $\mathrm{MC}$ & $\mathrm{MCZ}$ & $\mathrm{MZ}$ & MZP & MP & ME & \\
\hline \multirow[t]{11}{*}{ EPMA } & $\operatorname{Py}(n=2)$ & & & & & & & 0.02 & 0.02 & & 0.02 \\
\hline & $\mathrm{Sp}(n=289)$ & & 0.05 & & 0.19 & 0.15 & 0.03 & 0.15 & 2.13 & & 0.14 \\
\hline & & & & & $(0.02-1.73)$ & $(0.02-0.82)$ & $(0.02-0.15)$ & $(0.02-0.50)$ & $(1.39-4.30)$ & & $\begin{array}{c}(0.03-4.30) \\
0.07\end{array}$ \\
\hline & Cpy $(n=113)$ & & $\begin{array}{c}0.02 \\
(0.02-0.03)\end{array}$ & & $\begin{array}{c}0.09 \\
(0.02-0.15)\end{array}$ & $\begin{array}{c}0.06 \\
(0.02-0.12)\end{array}$ & $\begin{array}{c}0.06 \\
(0.02-0.12)\end{array}$ & 0.02 & $\begin{array}{c}0.10 \\
(0.05-0.12)\end{array}$ & $\begin{array}{c}0.09 \\
(0.05-0.12)\end{array}$ & $\begin{array}{c}0.07 \\
(0.02-0.15)\end{array}$ \\
\hline & $\operatorname{Gn}(n=1)$ & & & & & & & & 0.02 & & 0.02 \\
\hline & $\mathrm{Td}(n=8)$ & & & & & 0.03 & 0.05 & & & $\begin{array}{c}0.06 \\
(0.05-0.07)\end{array}$ & $\begin{array}{c}0.05 \\
(0.03-0.07)\end{array}$ \\
\hline & $\operatorname{Tn}(n=9)$ & & & & $\begin{array}{c}0.26 \\
(0.22-0.37)\end{array}$ & & & & & & $\begin{array}{c}0.26 \\
(0.22-0.37)\end{array}$ \\
\hline & $\operatorname{Stn}(n=36)$ & & & & 1.47 & $\begin{array}{c}1.30 \\
(0.98-1.66)\end{array}$ & $\begin{array}{c}0.50 \\
(0.10-1.12)\end{array}$ & $\begin{array}{c}0.15 \\
(0.10-0.20)\end{array}$ & & $\begin{array}{c}1.05 \\
(0.11-3.21)\end{array}$ & $\begin{array}{c}0.99 \\
(0.10-3.21)\end{array}$ \\
\hline & Fe-Kst $(n=19)$ & & & & & $\begin{array}{c}0.21 \\
(0.06-0.35)\end{array}$ & $\begin{array}{c}0.19 \\
(0.06-0.35)\end{array}$ & 0.06 & & & $\begin{array}{c}0.20 \\
(0.06-0.35)\end{array}$ \\
\hline & Kst $(n=13)$ & & & & & 0.14 & 0.07 & & & & 0.11 \\
\hline & $\operatorname{Roq}(n=3)$ & & & & & & & & & $\begin{array}{c}44.64 \\
(40.84-46.69)\end{array}$ & \\
\hline \multirow[t]{2}{*}{ SEM } & $\operatorname{Roq}(n=5)$ & & & & & $\begin{array}{c}41.89 \\
(36.97-43.85)\end{array}$ & & & & & \\
\hline & Roq-Sak $(n=5)$ & & & & 21.21 & $\begin{array}{c}25.75 \\
(17.28-34.22)\end{array}$ & & & & & \\
\hline
\end{tabular}

Py - pyrite; Sp - sphalerite; Cpy - chalcopyrite; Gn - galena; Td - tetrahedrite; Tn - tennantite; Stn - stannite; Fe-Kst - ferrokesterite; Kst - kesterite; Roq - roquesite; Roq-Sak - roquesite-sakuraiite; FC - copper stockwork; FE - barren stockwork; FZ - zinc stockwork; MC - massive copper ore; MCZ - massive copper-zinc ore; MZ massive zinc ore; MZP - massive zinc-lead ore; MP - massive lead ore; ME - barren massive ore. 
TABLE 8. Selenium content (wt.\%) of Neves-Corvo ore sulfides by means of EPMA and SEM-EDS analysis.

\begin{tabular}{|c|c|c|c|c|c|c|c|c|c|c|}
\hline & & \multicolumn{2}{|c|}{ Stockwork ore } & \multicolumn{6}{|c|}{ Massive sulfide ore } & \multirow[b]{2}{*}{ Avg. Comp. } \\
\hline & & FE & $\mathrm{FC}$ & $\mathrm{MC}$ & $\mathrm{MCZ}$ & $\mathrm{MZ}$ & MZP & MP & ME & \\
\hline \multirow[t]{24}{*}{ EPMA } & $\mathrm{Py}(n=30)$ & 0.08 & 0.07 & 0.07 & 0.13 & 0.13 & & & & 0.09 \\
\hline & $\operatorname{Sp}(n=28)$ & $(0.05-0.11)$ & $\begin{array}{c}(0.04-0.13) \\
0.05\end{array}$ & $(0.04-0.12)$ & $\begin{array}{c}(0.04-0.25) \\
0.07\end{array}$ & $\begin{array}{c}(0.06-0.20) \\
0.06\end{array}$ & 0.06 & 0.04 & & $\begin{array}{c}(0.04-0.25) \\
0.06\end{array}$ \\
\hline & & & & & $(0.04-0.14)$ & $(0.04-0.12)$ & & & & $(0.04-0.14)$ \\
\hline & Cpy $(n=37)$ & 0.04 & $\begin{array}{c}0.06 \\
(0.05-0.08)\end{array}$ & $\begin{array}{c}0.05 \\
(0.04-0.05)\end{array}$ & $\begin{array}{c}0.07 \\
(0.04-0.11)\end{array}$ & & 0.04 & & $\begin{array}{c}0.06 \\
(0.06-0.07)\end{array}$ & $\begin{array}{c}0.06 \\
(0.04-0.11)\end{array}$ \\
\hline & Gn $(n=67)$ & 0.46 & 2.09 & 6.32 & 1.49 & & 0.14 & & & 1.00 \\
\hline & & $(0.45-0.47)$ & $(1.12-3.80)$ & $(0.40-15.56)$ & $(0.06-4.88)$ & & $(0.04-0.31)$ & & & $(0.04-15.56)$ \\
\hline & Apy $(n=48)$ & & 0.40 & 0.24 & 0.28 & 0.11 & 0.11 & & & 0.26 \\
\hline & & & $(0.05-0.82)$ & $(0.08-0.93)$ & $(0.09-0.75)$ & $(0.10-0.12)$ & $(0.10-0.13)$ & & & $(0.05-0.93)$ \\
\hline & Cbt $(n=18)$ & & $\begin{array}{c}0.32 \\
(0.12-0.61)\end{array}$ & & 0.19 & & & & & $\begin{array}{c}0.32 \\
(0.12-0.61)\end{array}$ \\
\hline & Gdt $(n=5)$ & & 0.17 & 0.50 & & & & & & 0.44 \\
\hline & 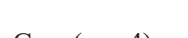 & & & $(0.41-0.60)$ & & & & & & $(0.17-0.60)$ \\
\hline & Carr $(n=4)$ & & & $\begin{array}{c}0.19 \\
(0.17-0.21)\end{array}$ & & & & & & \\
\hline & $\mathrm{Td}(n=28)$ & & 0.13 & 0.13 & 0.09 & 0.05 & & & 0.10 & 0.10 \\
\hline & & & $(0.13-0.14)$ & $(0.04-0.25)$ & $(0.05-0.13)$ & & & & $(0.10-0.11)$ & $(0.04-0.25)$ \\
\hline & $\operatorname{Tn}(n=13)$ & & & $\begin{array}{c}0.11 \\
(0.06-013)\end{array}$ & $\begin{array}{c}0.13 \\
(0.04-020)\end{array}$ & & & & & $\begin{array}{c}0.11 \\
(0.4-020)\end{array}$ \\
\hline & $\operatorname{Stn}(n=16)$ & & & $(0.06-0.13)$ & $(0.04-0.20)$ & & & & & $\begin{array}{c}(0.04-0.20) \\
0.11\end{array}$ \\
\hline & $\sin (n=10)$ & & & 0.07 & $\begin{array}{c}0.13 \\
(0.07-0.17)\end{array}$ & & & & $\begin{array}{c}0.06 \\
(0.04-0.07)\end{array}$ & $\begin{array}{c}0.11 \\
(0.04-0.17\end{array}$ \\
\hline & Kst $(n=5)$ & & & & & $\begin{array}{c}0.15 \\
(0.08-0.33)\end{array}$ & & & & \\
\hline & Mwt $(n=7)$ & & & $\begin{array}{c}0.21 \\
(0.13-0.26)\end{array}$ & & & & & & \\
\hline & $\operatorname{Nmt}(n=7)$ & & & $\begin{array}{c}24.81 \\
(24.21-25.56)\end{array}$ & & & & & & \\
\hline & Gtv $(n=1)$ & & 0.15 & & & & & & & \\
\hline & Clt $(n=1)$ & & 1.63 & & & & & & & \\
\hline & Jnt (?) $(n=3)$ & & 7.33 & & & & & & & \\
\hline & & & $(4.77-9.79)$ & & & & & & & \\
\hline
\end{tabular}




\section{J. R. S. CARVALHO ETAL.}

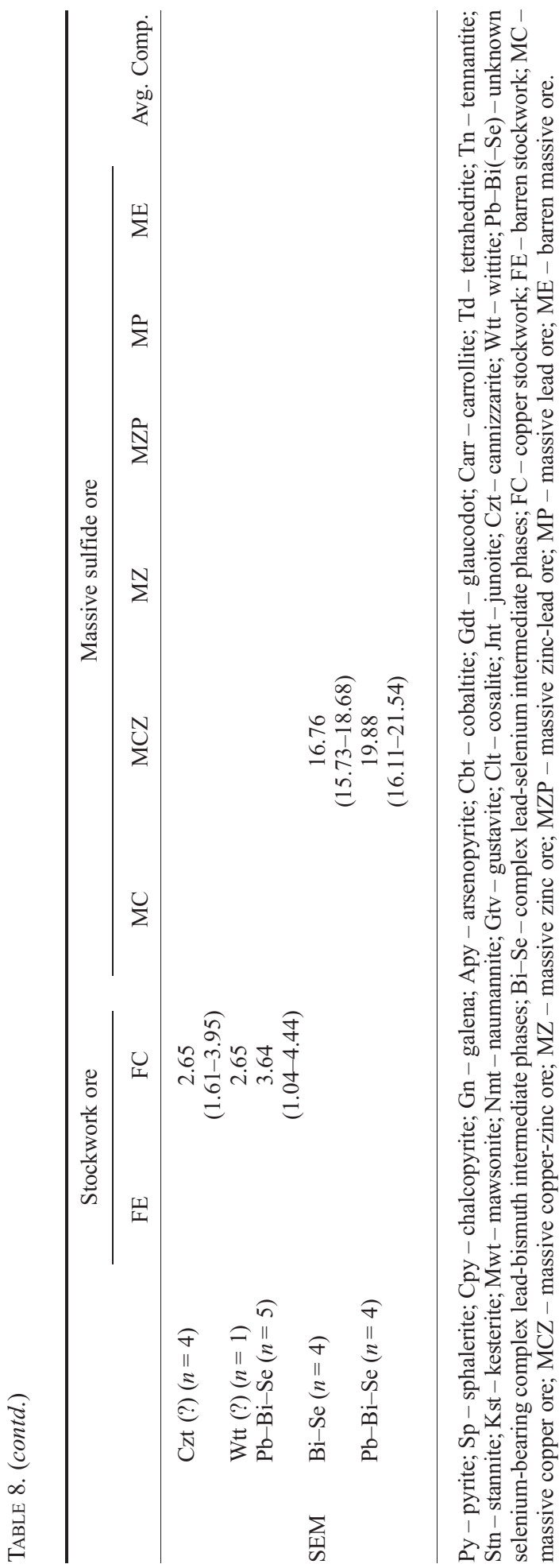

ore minerals analysed are present as atomic substitutions in the crystal lattice (e.g. sphalerite, chalcopyrite). This would also be in accordance with the observations of other authors (e.g. Cook et al., 2009; George et al., 2016). It is not surprising, therefore, that the main In- and Sebearing sulfides were found to follow roughly the commonly described substitution mechanisms. The main substitution mechanisms for In incorporation into sulfides include (1) $2 \mathrm{Zn}^{2+}$ or $3 \mathrm{Zn}^{2+}$ replacement by $\mathrm{Cu}^{+}+\mathrm{In}^{3+}$ or $\mathrm{Cu}^{+}+\mathrm{In}^{3+}+\mathrm{Fe}^{2+}$ in sphalerite, respectively; (2) $\mathrm{Fe}^{3+}$ replacement by $\mathrm{Cu}^{+}+$ $\mathrm{In}^{3+}$ in chalcopyrite, and (3) $\mathrm{Cu}^{+}+\mathrm{Sn}^{4+}$ replacement by $\left(\mathrm{Fe}^{2+}, \mathrm{Zn}^{2+}\right)+\mathrm{In}^{3+}$ in the stannite group minerals ( $c f$. Johan, 1988; Ohta, 1989; Bente and Doering, 1995; Schwarz-Schampera, 2000; Benzaazoua et al., 2003; Sinclair et al., 2006; Cook et al., 2009; Frenzel et al., 2016). Selenium on the other hand usually substitutes for sulfur (cf. Large and Mumme, 1975; Healy and Petruk, 1992; Huston et al., 1995a,b; Marcoux et al., 1996). As reported for fossil and present-day deposits, incorporation of both In and Se into the sulfide lattice is favoured by higher formation temperatures (cf. Large and Mumme, 1975; Auclair et al., 1987; Huston et al., 1995a,b; Zabarina et al., 1961 in Moura et al., 2007; Frenzel et al., 2016), which is consistent with the deposit-scale In and $\mathrm{Se}$ distribution.

Although In and Se appear to be present mostly in solid solution, this is not necessarily the case for all other elements measured by EPMA. For instance, $\mathrm{Cu}$ in sphalerite seems to be related frequently to nano-inclusions of chalcopyrite (chalcopyrite disease). These relationships are discussed for each mineral in more detail below. In general, low concentrations of $\mathrm{Cu}, \mathrm{Pb}$ and $\mathrm{Zn}$ detected in minerals where these elements are not stoichiometric components appear to be due to either inclusions or secondary X-ray fluorescence effects generated by adjacent $\mathrm{Cu}, \mathrm{Pb}$ and $\mathrm{Zn}$ bearing minerals rather than actual substitution within the mineral lattice.

\section{Sphalerite}

The variation of In and other major and trace elements in sphalerite determined by EPMA are shown in Table 9 and in Fig. 8 as inter-element plots. In general, the variations in the trace-element contents of sphalerite are relatively subtle. However, despite the significant annealing and recrystallization effects already described, it is often possible to discriminate the various ore types 
TABLE 9. Average chemical composition of sphalerite for the different ore types from the Neves-Corvo deposit by means of EPMA.

\begin{tabular}{|c|c|c|c|c|c|c|c|c|c|c|c|}
\hline & \multirow{2}{*}{$\begin{array}{l}\text { Avg. } \\
\text { Comp. }\end{array}$} & \multicolumn{3}{|c|}{ Stockwork ore } & \multirow[b]{2}{*}{ Avg. } & \multicolumn{5}{|c|}{ Massive sulfide ore } & \multirow[b]{2}{*}{ Avg. } \\
\hline & & $\mathrm{FE}$ & $\mathrm{FC}$ & $\mathrm{FZ}$ & & $\mathrm{MC}$ & $\mathrm{MCZ}$ & $\mathrm{MZ}$ & MZP & MP & \\
\hline$n$ & 595 & 29 & 119 & 64 & 212 & 40 & 120 & 155 & 64 & 4 & 383 \\
\hline S & 32.79 & 33.25 & 32.54 & 33.39 & 32.83 & 32.37 & 32.65 & 32.77 & 33.00 & 33.27 & 32.74 \\
\hline $\mathrm{Fe}$ & 2.35 & 1.37 & 2.30 & 1.31 & 1.96 & 2.69 & 2.13 & 3.15 & 2.18 & 3.10 & 2.62 \\
\hline $\mathrm{Cu}$ & 0.32 & 0.31 & 0.22 & 0.13 & 0.22 & 0.39 & 0.48 & 0.21 & 0.22 & 1.45 & 0.36 \\
\hline $\mathrm{Zn}$ & 64.06 & 64.98 & 64.27 & 65.00 & 64.54 & 63.56 & 63.84 & 63.57 & 64.46 & 59.83 & 63.76 \\
\hline $\mathrm{Pb}$ & 0.13 & 0.12 & 0.12 & 0.12 & 0.12 & 0.12 & 0.20 & 0.12 & 0.14 & 0.13 & 0.14 \\
\hline As & 0.10 & 0.04 & 0.04 & 0.06 & 0.05 & 0.09 & 0.10 & 0.06 & 0.13 & 0.09 & 0.10 \\
\hline $\mathrm{Ni}$ & 0.04 & 0.04 & 0.03 & 0.04 & 0.04 & bdl & bdl & 0.04 & 0.04 & bdl & 0.04 \\
\hline $\mathrm{Sb}$ & 0.05 & 0.03 & 0.04 & 0.04 & 0.03 & 0.05 & 0.13 & 0.03 & 0.04 & 0.06 & 0.06 \\
\hline $\mathrm{Sn}$ & 0.12 & bdl & 0.05 & 0.06 & 0.05 & 0.30 & 0.08 & 0.09 & 0.18 & bdl & 0.14 \\
\hline $\mathrm{Co}$ & 0.02 & 0.02 & 0.02 & 0.02 & 0.02 & 0.02 & 0.02 & 0.02 & 0.02 & bdl & 0.02 \\
\hline $\mathrm{Mn}$ & 0.03 & 0.05 & 0.02 & 0.03 & 0.04 & 0.01 & 0.01 & 0.02 & 0.02 & bdl & 0.02 \\
\hline $\mathrm{Hg}$ & 0.21 & 0.34 & 0.41 & 0.50 & 0.38 & 0.15 & 0.17 & 0.15 & 0.16 & 0.15 & 0.16 \\
\hline $\mathrm{Ag}$ & 0.04 & 0.05 & 0.04 & 0.04 & 0.04 & bdl & 0.04 & 0.04 & 0.03 & 0.05 & 0.04 \\
\hline $\mathrm{Au}$ & 0.09 & bdl & bdl & 0.09 & 0.09 & bdl & bdl & bdl & bdl & bdl & bdl \\
\hline $\mathrm{Bi}$ & 0.15 & bdl & bdl & bdl & bdl & bdl & bdl & 0.13 & 0.18 & bdl & 0.15 \\
\hline $\mathrm{Ge}$ & 0.01 & 0.01 & 0.01 & 0.02 & 0.01 & bdl & 0.00 & 0.01 & 0.01 & bdl & 0.01 \\
\hline $\mathrm{Se}$ & 0.06 & bdl & 0.05 & bdl & 0.05 & bdl & 0.07 & 0.06 & 0.06 & 0.04 & 0.06 \\
\hline In & 0.14 & bdl & 0.05 & bdl & 0.05 & 0.19 & 0.15 & 0.03 & 0.15 & 2.13 & 0.17 \\
\hline $\mathrm{Cd}$ & 0.14 & 0.09 & 0.13 & 0.07 & 0.11 & 0.20 & 0.20 & 0.15 & 0.12 & 0.12 & 0.16 \\
\hline $\mathrm{Te}$ & bdl & bdl & bdl & bdl & bdl & bdl & bdl & bdl & bdl & bdl & bdl \\
\hline Total & 100.86 & 100.69 & 100.34 & 100.90 & 100.62 & 100.16 & 100.27 & 100.64 & 101.13 & 100.42 & 100.74 \\
\hline
\end{tabular}

FC - copper stockwork ore; FE - barren stockwork; FZ - zinc stockwork ore; $\mathrm{MC}$ - massive copper ore; $\mathrm{MCZ}$ - massive copper-zinc ore; $\mathrm{MZ}$ - massive zinc ore; $\mathrm{MZP}$ massive zinc-lead ore; MP - massive lead ore; bdl - below detection limit. 


\section{J. R. S. CARVALHO ETAL.}
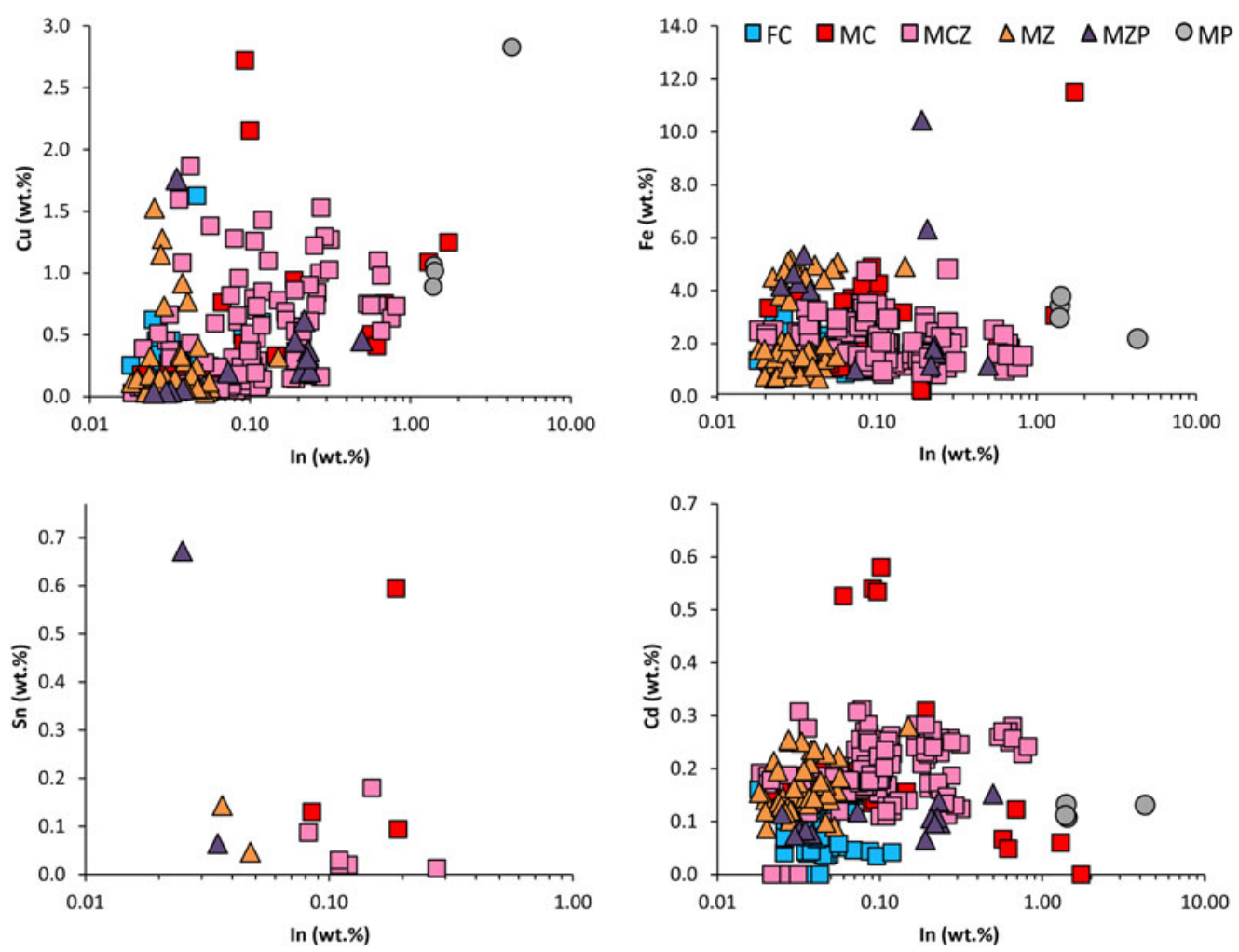

FIG. 8. Inter-element plots for selected trace elements in sphalerite from the Neves-Corvo deposit. Abbreviations as in Table 9 .

studied on the basis of the $\mathrm{Fe}, \mathrm{Cu}, \mathrm{Sn}, \mathrm{Cd}$ and $\mathrm{In}$ contents in sphalerite. Concentrations of other trace elements in sphalerite, such as $\mathrm{Pb}, \mathrm{As}, \mathrm{Ni}, \mathrm{Sb}, \mathrm{Co}$ and $\mathrm{Ag}$ are remarkably uniform and usually quite low ( $\leq 0.2$ wt. $\%$, Carvalho, 2016).

From an overall perspective, sphalerite in the massive sulfide ores displays higher concentrations in trace elements than that in the stockwork ores. On average, the Fe content is fairly low (2.3 wt.\%), although it can reach up to $11.5 \mathrm{wt} \%$ (marmatite composition). This is consistent with the predominant yellowish brown colour and red-brown internal reflections shown by sphalerite under reflected light. However, no obvious trend has been detected between the Fe content of sphalerite and the different ore types and generations (Carvalho, 2016). The largest concentrations of $\mathrm{Fe}$ in sphalerite were nevertheless measured in the $\mathrm{Cu}$-rich stockwork (FC) and massive ores (MC), which is in good agreement with the higher formation temperatures expected for these ore types. However, considerably high $\mathrm{Fe}$ concentrations in sphalerite grains were also found in the low-temperature massive $\mathrm{Zn}(\mathrm{MZ})$ and $\mathrm{Pb}$-rich (MZP) ore types. In fact, some analyses of single sphalerite grains in both these ore types gave $\mathrm{Fe}$ concentrations that attain the composition of marmatite. Copper concentration in sphalerite is consistently higher in massive $\mathrm{Cu}-\mathrm{Zn}(\mathrm{MCZ})$ ores, where it averages $0.48 \mathrm{wt} . \%$ (up to a maximum of 1.86 wt.\%). However, $\mathrm{Cu}$ in sphalerite also reached elevated concentrations in the $\mathrm{MC}$ (up to $2.7 \mathrm{wt} . \%$ ) and in the MP (up to 2.83 wt.\%) ore types. In the low-temperature MZ and MZP ore types, the maximum $\mathrm{Cu}$ concentrations in sphalerite are lower, reaching up to $1.53 \mathrm{wt} \%$ (average $0.21 \mathrm{wt} . \%$ ) and $1.76 \mathrm{wt} . \%$ (average $0.22 \mathrm{wt} . \%$ ), respectively. The notable maximum $\mathrm{Cu}$ contents in sphalerite grains from the different ore types result mostly from the presence of micro-inclusions of chalcopyrite within sphalerite, which occur either as finegrained dispersed blebs, or as blebs oriented along the crystallographic directions of sphalerite (e.g. Fig. $3 e, f)$.

The Sn contents in sphalerite from both the stockwork and massive sulfide ores mostly fall 
below MDL (0.03 wt.\%), particularly in the barren stockwork (FE) and in the massive Pb-rich (MP) ore types. In some cases, however, single sphalerite grains ( $>12 \%$ of the sphalerite analysed) in the $\mathrm{Zn}$ stockwork (FZ) and $\mathrm{Cu}$ stockwork (FC) ore types display detectable Sn (up to $0.10 \mathrm{wt} . \%$, averaging 0.06 wt. $\%$ in FZ; up to 0.05 wt. $\%$, averaging 0.05 wt. \% in FC). In the massive sulfide ores, modest $\mathrm{Sn}$ contents in sphalerite are frequent in the MZP ore type. About $14 \%$ of the sphalerite grains in this type of ore show Sn contents above MDL, reaching up to $0.70 \mathrm{wt} . \%$. In the $\mathrm{MC}$ ore, only $7 \%$ of the sphalerite grains analysed have Sn contents above MDL and, in these, their maximum $\mathrm{Sn}$ content reaches $0.62 \mathrm{wt} . \%$. In the remaining ore types, sphalerite with Sn contents above MDL were only found in about $6 \%$ of the grains analysed. The highest $\mathrm{Sn}$ concentrations in sphalerite are thought to result from the presence of nano-, and/or small micro-inclusions of cassiterite, which are relatively common in the IPB massive sulfides (Marcoux et al., 1998). However, despite very detailed petrographic inspection, we were not able to observe cassiterite inclusions in our sphalerite samples. In addition, or as an alternative to this possibility, these high Sn contents in sphalerite may correspond to intergrowths with mineral phases belonging to the sphalerite-stannite solid solution series. In fact, variably sized blebs $(\leq 1- \pm 20 \mu \mathrm{m})$ or films of Sn-sulfosalts, such as stannite, kesterite, ferrokesterite, or intermediate phases, were observed, especially at contacts between sphalerite and the gangue minerals.

Cadmium concentrations in sphalerite grains are higher in the massive sulfide ores, and particularly in the $\mathrm{MC}$ ore type from the Lombador orebody. In the $\mathrm{MC}$ ore type, the $\mathrm{Cd}$ concentration reaches as much as 0.58 wt. $\%$, whereas in the remaining ore types, $\mathrm{Cd}$ concentrations are consistently $<0.30 \mathrm{wt} . \%$.

Selenium contents above MDL were detected in $\sim 5 \%$ of the sphalerite grains analysed. High Se contents in sphalerite were mostly found in sphalerite grains from the massive sulfide ores types, in particular in those from the MCZ ore type (up to 0.14 wt.\%). Nevertheless, significant Se concentrations were also found in some single sphalerite grains from $\mathrm{Zn}$-rich ore types (up to 0.12 wt.\%). In the stockwork ores, Se-bearing sphalerite was only found in the FC ore type (up to 0.08 wt. $\%$; average 0.05 wt. $\%$ ).

Finally, In concentrations in sphalerite reach up to $4.30 \mathrm{wt} . \%$ (average $0.14 \mathrm{wt} . \%$ ). Although the highest In concentration in sphalerite were measured locally in a sample from the massive $\mathrm{Pb}$ (MP) ore from the Lombador orebody (4.30 wt.\% In), sphalerite grains from the $\mathrm{Cu}$-rich ores (FC, MC and MZC) consistently display higher In contents (up to $1.73 \mathrm{wt} . \%$ ) than those in the remaining ore types. In fact, the In concentration in sphalerite correlates roughly with $\mathrm{Cu}$ (Fig. 8), in particular in the $\mathrm{MCZ}$ ore, but it shows no evident correlation with $\mathrm{Fe}, \mathrm{Sn}$ or $\mathrm{Cd}$ (neither with other elements such as $\mathrm{Bi}, \mathrm{Ag}$, or $\mathrm{As}$ ). Moreover, high-resolution SEM images coupled with semi-quantitative analysis have shown very small micro-inclusions of In-bearing minerals, such as roquesite and/or roquesite-sakuraiite intermediate phases, within chalcopyrite-diseased sphalerite grains. Although it was not possible to acquire high-contrast BSE images of these particular sphalerite grains, detailed microscopic inspection have shown oriented chalcopyrite blebs in these grains, associated with late chalcopyrite ( \pm tetrahedrite) ribbons formed through remobilization and exsolution processes triggered by tectonic deformation.

\section{Chalcopyrite}

Chalcopyrite shows, in general, low concentrations (typically $<0.15 \mathrm{wt} . \%$ ) of most trace elements. Nevertheless, noticeable concentrations of $\mathrm{Zn}, \mathrm{Pb}$, $\mathrm{Sn}$ and In and, to a lesser extent, Se enable some discrimination between the different ore types (Table 10), as well as among the different generations of chalcopyrite. Concentrations of other trace elements in chalcopyrite are relatively uniform and usually very small $(<0.1 \mathrm{wt} . \%)$ or $<$ MDL. About $74 \%$ of the chalcopyrite grains analysed exhibit $\mathrm{Zn}$ concentrations above MDL, reaching up to $0.90 \mathrm{wt} . \%$ (average $0.12 \mathrm{wt} . \%$ ). However, there is no obvious relationship between the $\mathrm{Zn}$ content of chalcopyrite (as well as that of $\mathrm{Sn}$ or In), and the different ore types. Chalcopyrite grains in the $\mathrm{FZ}$ and $\mathrm{MZ}$ ores display, on average, the largest $\mathrm{Zn}$ contents (0.23 and $0.26 \mathrm{wt} . \%$, respectively), whereas in the remaining ore types, $\mathrm{Zn}$ concentration in chalcopyrite is usually $<0.1 \mathrm{wt} . \%$. Nevertheless, high zinc concentrations (up to 0.85 wt.\%) were found in single chalcopyrite grains from the $\mathrm{FC}, \mathrm{MC}$ and $\mathrm{MCZ}$ ores, indicating that higher formation temperatures would have favoured incorporation of $\mathrm{ZnS}$ into the chalcopyrite structure. Lead concentrations above MDL (0.09 wt.\%) occur in $\sim 12 \%$ of the chalcopyrite grains analysed, and reach up to $0.54 \mathrm{wt} . \%$ (average 0.13 wt. $\% \mathrm{~Pb}$ ). Chalcopyrite from the FC ore type possesses, on average, the highest $\mathrm{Pb}$ contents (mean $0.25 \mathrm{wt} \% \%$; ranging from 0.09 to $0.54 \mathrm{wt} \%$ ), 
TABLE 10. Average chemical composition of chalcopyrite for the different ore types from the Neves-Corvo deposit by means of EPMA.

\begin{tabular}{|c|c|c|c|c|c|c|c|c|c|c|c|c|}
\hline \multirow[b]{2}{*}{$n$} & \multirow{2}{*}{$\begin{array}{c}\text { Avg. Comp. } \\
381\end{array}$} & \multicolumn{4}{|c|}{ Stockwork ore } & \multicolumn{7}{|c|}{ Massive sulfide ore } \\
\hline & & $\begin{array}{l}\mathrm{FE} \\
25\end{array}$ & $\begin{array}{c}\mathrm{FC} \\
90\end{array}$ & $\begin{array}{l}\mathrm{FZ} \\
28\end{array}$ & $\begin{array}{c}\text { Avg. } \\
143\end{array}$ & $\begin{array}{c}\mathrm{MC} \\
63\end{array}$ & $\begin{array}{c}\mathrm{MCZ} \\
108\end{array}$ & $\begin{array}{c}\text { MZ } \\
19\end{array}$ & $\begin{array}{c}\text { MZP } \\
20\end{array}$ & $\begin{array}{c}\text { MP } \\
5\end{array}$ & $\begin{array}{c}\mathrm{ME} \\
18\end{array}$ & $\begin{array}{c}\text { Avg. } \\
233\end{array}$ \\
\hline S & 34.61 & 35.08 & 34.31 & 35.10 & 34.60 & 34.56 & 34.68 & 34.49 & 34.46 & 34.75 & 34.74 & 34.62 \\
\hline $\mathrm{Fe}$ & 30.61 & 30.87 & 30.63 & 30.81 & 30.71 & 30.58 & 30.58 & 30.36 & 30.64 & 29.87 & 30.69 & 30.56 \\
\hline $\mathrm{Cu}$ & 34.20 & 34.14 & 34.22 & 33.91 & 34.15 & 34.20 & 34.29 & 34.19 & 34.17 & 34.57 & 34.01 & 34.23 \\
\hline $\mathrm{Zn}$ & 0.12 & 0.10 & 0.12 & 0.23 & 0.14 & 0.11 & 0.10 & 0.26 & 0.11 & 0.09 & 0.05 & 0.11 \\
\hline $\mathrm{Pb}$ & 0.13 & 0.13 & 0.25 & 0.13 & 0.16 & 0.13 & 0.12 & 0.14 & 0.10 & 0.10 & 0.12 & 0.12 \\
\hline As & 0.08 & bdl & 0.11 & bdl & 0.11 & 0.04 & 0.07 & 0.15 & 0.06 & bdl & bdl & 0.08 \\
\hline $\mathrm{Ni}$ & 0.04 & 0.04 & 0.04 & 0.06 & 0.04 & bdl & bdl & bdl & bdl & bdl & bdl & bdl \\
\hline $\mathrm{Sb}$ & 0.03 & 0.03 & 0.03 & 0.04 & 0.03 & bdl & 0.04 & 0.02 & bdl & bdl & bdl & 0.03 \\
\hline $\mathrm{Sn}$ & 0.08 & 0.07 & 0.06 & 0.06 & 0.06 & 0.08 & 0.07 & 0.16 & 0.07 & 0.03 & 0.06 & 0.08 \\
\hline $\mathrm{Co}$ & 0.05 & 0.06 & 0.05 & 0.06 & 0.05 & 0.05 & 0.05 & 0.04 & 0.05 & bdl & 0.04 & 0.05 \\
\hline $\mathrm{Mn}$ & 0.02 & 0.02 & 0.03 & 0.02 & 0.02 & bdl & bdl & bdl & bdl & bdl & bdl & bdl \\
\hline $\mathrm{Hg}$ & 0.20 & bdl & bdl & 0.37 & 0.37 & 0.09 & 0.10 & bdl & bdl & bdl & 0.09 & 0.10 \\
\hline $\mathrm{Ag}$ & 0.04 & 0.04 & 0.05 & 0.05 & 0.05 & 0.03 & 0.04 & bdl & bdl & bdl & bdl & 0.04 \\
\hline $\mathrm{Au}$ & 0.11 & bdl & bdl & bdl & bdl & bdl & 0.11 & bdl & bdl & bdl & bdl & 0.11 \\
\hline $\mathrm{Bi}$ & 0.12 & bdl & bdl & bdl & bdl & 0.13 & bdl & bdl & 0.10 & bdl & bdl & 0.12 \\
\hline $\mathrm{Ge}$ & 0.01 & 0.01 & 0.01 & 0.01 & 0.01 & 0.00 & 0.00 & 0.01 & 0.01 & bdl & 0.00 & 0.00 \\
\hline $\mathrm{Se}$ & 0.06 & 0.04 & 0.06 & bdl & 0.05 & 0.05 & 0.07 & bdl & 0.04 & bdl & 0.06 & 0.06 \\
\hline In & 0.07 & bdl & 0.02 & bdl & 0.02 & 0.09 & 0.06 & 0.06 & 0.02 & 0.10 & 0.09 & 0.07 \\
\hline $\mathrm{Cd}$ & 0.04 & 0.04 & 0.04 & 0.04 & 0.04 & 0.04 & 0.04 & bdl & 0.04 & bdl & 0.04 & 0.04 \\
\hline $\mathrm{Tl}$ & bdl & bdl & bdl & bdl & bdl & bdl & bdl & bdl & bdl & bdl & bdl & bdl \\
\hline $\mathrm{Te}$ & bdl & bdl & bdl & bdl & bdl & bdl & bdl & bdl & bdl & bdl & bdl & bdl \\
\hline Total & 100.64 & 100.67 & 100.03 & 100.88 & 100.61 & 100.19 & 100.43 & 99.86 & 99.86 & 99.50 & 100.00 & 100.43 \\
\hline
\end{tabular}

(1)

FC - copper stockwork ore; FE - barren stockwork; FZ - zinc stockwork ore; MC - massive copper ore; MCZ - massive copper-zinc ore; MZ - massive zinc ore; MZP massive zinc-lead ore; MP - massive lead ore; ME - barren massive ore; bdl - below detection limit. 
whereas in the remaining ore types, $\mathrm{Pb}$ contents in chalcopyrite are generally $<0.15 \mathrm{wt} . \%$. Traces of $\mathrm{Sn}$ (0.03-0.44 wt.\%, averaging 0.08 wt.\%) in chalcopyrite grains are also relatively common, occurring above MDL in $\sim 46 \%$ of the chalcopyrite grains analysed. Generally speaking, Sn concentrations in chalcopyrite grains are greater in the massive sulfide ores, particularly in the MZ ore type, where it can reach up to $0.41 \mathrm{wt} \%$, and occur in almost $95 \%$ of the chalcopyrite grains analysed. Tin contents in chalcopyrite from the $\mathrm{MC}$ and $\mathrm{MCZ}$ ore types reach up to 0.44 and $0.23 \mathrm{wt} . \%$, respectively, and occur in $\sim 60 \%$ of the chalcopyrite grains analysed. However, the higher Sn concentrations (the same for $\mathrm{Zn}$ and $\mathrm{Pb}$ ) should reflect the presence of very fine-grained $(<5 \mu \mathrm{m})$ blebs or films of stannite along the chalcopyrite grain boundaries. This is corroborated by the fact that $>65 \%$ of the chalcopyrite grains that fill ribbons and display visible (under the microscope) stannite or stannite \pm sphalerite blebs along grain boundaries, show $\mathrm{Sn}$ contents well above MDL. Traces of In above MDL (0.02 wt.\%) and ranging up to $0.15 \mathrm{wt} . \%$ (average 0.07 wt. $\%$ ) were found in $~ 30 \%$ of the chalcopyrite grains analysed, particularly in those from the massive $\mathrm{Cu}$-rich ore types ( $\mathrm{MC}$ and $\mathrm{MCZ}$ ore types; Fig. 9). In these ore types, In concentrations in chalcopyrite reach as much as $0.15 \mathrm{wt} . \%$, and correlate roughly with $\mathrm{Zn}$, particularly in the $\mathrm{MCZ}$ ore type. No correlation was seen between In and other major or trace elements in the different ore types, except for some chalcopyrite grains from the $\mathrm{MZ}$ ore, where In correlates positively with $\mathrm{Sn}$ (Fig. 9). Chalcopyrite from the MZ, MP ores and massive barren sulfides (ME) show In concentrations of up to $0.12 \mathrm{wt} . \%$ (averaging $0.06 \%, 0.10 \%$ and 0.09 wt.\% In, respectively), whereas in the MZP ore type, In concentration in chalcopyrite grains is usually below MDL. As for sphalerite, the higher In concentrations measured in chalcopyrite grains from the MZ, MZP, MP and ME ore types were found in remobilized chalcopyrite grains that fill chalcopyrite ribbons and/or carbonate(-quartz) + chalcopyrite ( \pm sphalerite, tetrahedrite, galena) veins and veinlets. This is particularly clear in the MP and ME ores, which show In concentrations between 0.05 and 0.12 wt.\% (avg. 0.10 wt.\%). Chalcopyrite in these ore types occurs almost exclusively as a late generation, resulting from tectonometamorphic remobilization. The high In concentrations found in these chalcopyrite grains result mostly from extremely fine-grained $(<5 \mu \mathrm{m})$ blebs and films of roquesite and/or a roquesite-sakuraiite intermediate phase that fill micro-fractures or occur along the grain boundaries (e.g. Fig. 4c).

Selenium concentrations in chalcopyrite grains mostly fall below MDL. Concentrations above MDL ( 0.04 wt. $\%$ ) only occur in $<10 \%$ of the grains analysed, where they reach up to $0.11 \mathrm{wt} \% \mathrm{Se}$ (average $0.07 \mathrm{wt} . \%$ ). The chalcopyrite grains with higher Se contents were found in the cupriferous ore types (FC, MC, MCZ; Fig. 9), and, in particular, in the MCZ ore samples representative of the Zambujal orebody, which resulted mostly from secondary copper enrichment. There, Se concentrations above MDL were found in $>60 \%$ of the chalcopyrite grains analysed, although no correlation is seen between $\mathrm{Se}$ and $\mathrm{Cu}$. Measurable $\mathrm{Se}$ contents ( $0.06 \mathrm{wt} . \%$ on average) were also found in remobilized chalcopyrite grains occurring in the $\mathrm{ME}$ ore, which result from extremely fine-grained $(<5 \mu \mathrm{m})$ inclusions of Se-bearing mineral phases such as galena, consistently with a positive correlation between $\mathrm{Se}$ and $\mathrm{Pb}$ in these crystals (Fig. 9).

\section{Stannite, kesterite, and ferrokesterite}

Stannite is the principal $\mathrm{Cu}$-Sn-sulfide found in several of the studied ore types. It deviates from its ideal chemical formula $\left(\mathrm{Cu}_{2} \mathrm{FeSnS}_{4}\right)$ due to incorporation of significant amounts of zinc, ascribed to intergrowths with kesterite and/or ferrokesterite (Table 11). Zinc concentrations (1.56-4.27 wt.\%, averaging $2.67 \mathrm{wt} . \%)$ tend to correlate with $\mathrm{Fe}$, which ranges from 9.83 to 12.73 wt.\% (averaging 11.38 wt.\%). $\mathrm{Fe} /(\mathrm{Fe}+\mathrm{Zn}$ ) ratios in stannite range between 0.75 and 0.90 (averaging 0.83 ), but show no obvious correlation with ore type. As a general tendency, lower Fe/ $(\mathrm{Fe}+\mathrm{Zn})(<0.83)$ can be found in stannite grains from the MCZ and MZ ores, whereas higher Fe/ $(\mathrm{Fe}+\mathrm{Zn})$ values $(>0.83)$ are found in stannite grains from the MZP ores. Stannite grains from the massive barren sulfides display both low and high $\mathrm{Fe} /(\mathrm{Fe}+\mathrm{Sn})$ values. The lack of an obvious $\mathrm{Fe} /$ $(\mathrm{Fe}+\mathrm{Zn})$ compositional trend that can be correlated with ore type again reflects the impact of tectonometamorphic overprinting. Copper concentrations in the stannite grains range between 27.25 and 30.07 wt.\% (averaging 28.91 wt.\%), whereas Sn concentrations range between 24.13 and 28.51 wt.\% (averaging 26.79 wt.\%). Stannite contains significant In concentrations (0.10-3.21 wt.\%, averaging $0.99 \mathrm{wt} . \%$ ), in particular in grains occurring in veinlets filled with remobilized stannite, either in massive $\mathrm{Cu}$-rich ores, or within massive barren sulfides. On average, stannite 

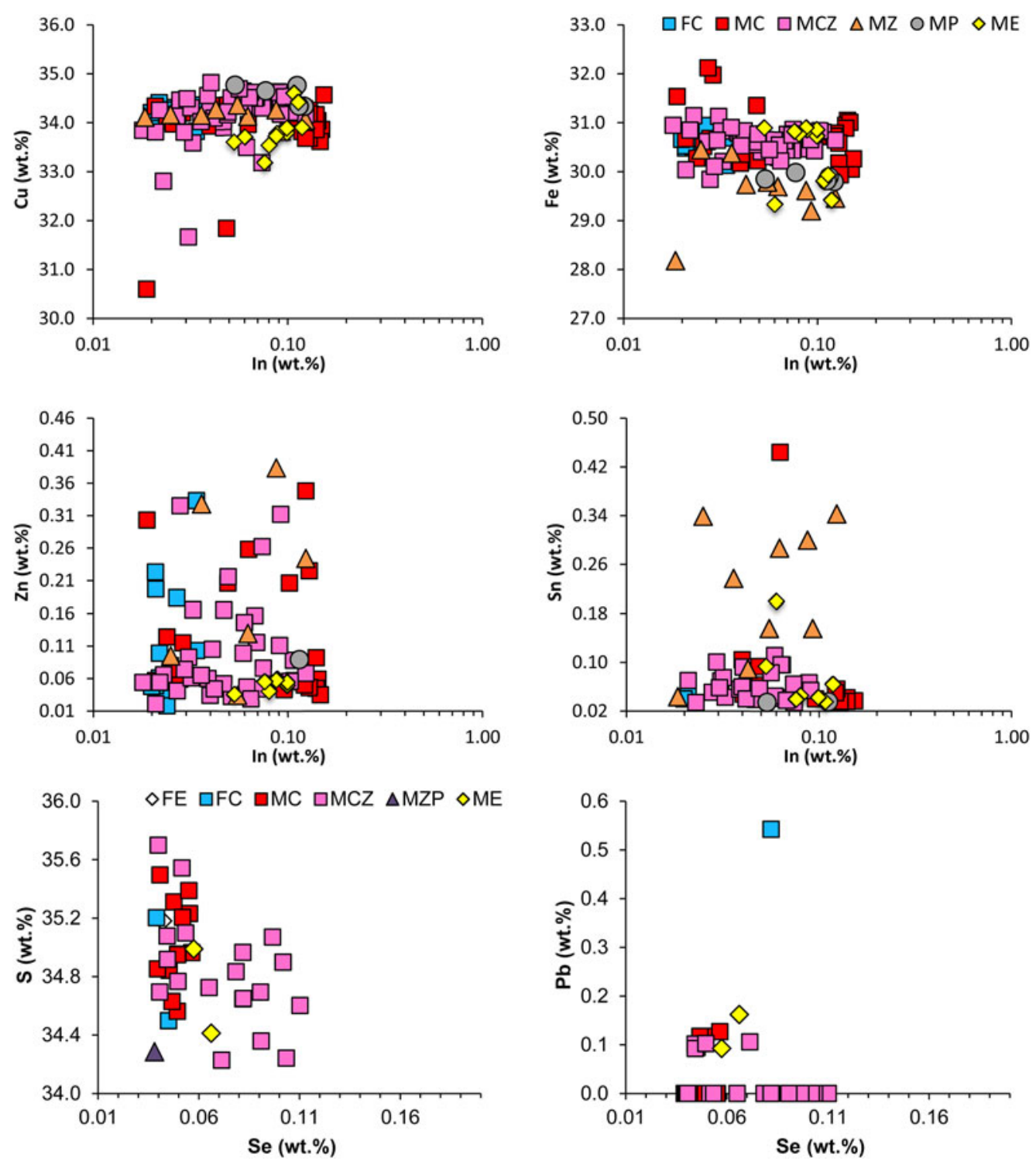

FIG. 9. Inter-elements plots for major and trace elements in chalcopyrite from the Neves-Corvo deposit. Abbreviations as in Table 10.

associated with late remobilization processes yields higher In concentrations (1.34 wt.\%) than the orerelated generation of stannite $(0.70 \mathrm{wt} \%$ In). Concentrations of other trace elements are generally $<0.1$ wt. $\%$, although detectable $\mathrm{Ag}$ (up to $0.25 \mathrm{wt}$. $\%$ ), $\mathrm{Hg}$ (up to 0.18 wt.\%) and Se (up to 0.17 wt.\%) can also be found in single stannite grains occurring in remobilized stannite veinlets. Indium in stannite correlates roughly with $\mathrm{Sn}, \mathrm{Cu}, \mathrm{Fe}$ and $\mathrm{Zn}$ (Fig. 10), which is consistent with the substitution mechanism proposed for stannite group minerals (e.g. Cook et al., 2009). Similar behaviour occurs in ferrokesterite and kesterite.

In ferrokesterite, $\mathrm{Cu}$ (up to $30.07 \mathrm{wt} . \%$ ), $\mathrm{Sn}$ (up to 28.25 wt.\%), $\mathrm{Zn}$ (up to $6.96 \mathrm{wt} . \%$ ) and $\mathrm{Fe}$ (up to 10.12 wt. \%) concentrations are relatively uniform among the various ore types. Ratios of (Total Fe)/ $(\mathrm{Fe}+\mathrm{Zn})$ range between 0.60 and 0.70 , and, as for 
TABLE 11. Average chemical composition of stannite, ferrokesterite and kesterite for the different ore types from the Neves-Corvo deposit by means of EPMA.

\begin{tabular}{|c|c|c|c|c|c|c|c|c|c|c|c|c|c|}
\hline \multirow[b]{4}{*}{$n$} & \multicolumn{6}{|c|}{ Stannite } & \multicolumn{4}{|c|}{ Ferrokesterite } & \multicolumn{3}{|c|}{ Kesterite } \\
\hline & \multirow{2}{*}{ Avg. Comp. } & \multicolumn{5}{|c|}{ Massive sulfide ore } & \multirow{2}{*}{ Avg. Comp. } & \multicolumn{3}{|c|}{ Massive sulfide ore } & \multirow{2}{*}{ Avg. Comp. } & \multicolumn{2}{|c|}{ M. sulfide ore } \\
\hline & & $\mathrm{MC}$ & $\mathrm{MCZ}$ & MZ & MZP & $\mathrm{ME}$ & & MCZ & MZ & MZP & & MCZ & $\mathrm{MZ}$ \\
\hline & 44 & 1 & 13 & 8 & 2 & 20 & 19 & 13 & 5 & 1 & 13 & 7 & 6 \\
\hline S & 29.22 & 29.11 & 29.27 & 29.24 & 29.50 & 29.16 & 29.00 & 29.10 & 28.87 & 28.34 & 28.95 & 28.84 & 29.08 \\
\hline $\mathrm{Fe}$ & 11.38 & 11.54 & 10.95 & 10.98 & 12.22 & 11.72 & 9.64 & 9.71 & 9.55 & 9.10 & 5.06 & 5.37 & 4.69 \\
\hline $\mathrm{Cu}$ & 28.91 & 29.25 & 28.41 & 28.85 & 29.44 & 29.19 & 29.25 & 29.48 & 28.76 & 28.64 & 29.34 & 29.47 & 29.20 \\
\hline $\mathrm{Zn}$ & 2.67 & 2.46 & 2.95 & 2.95 & 1.73 & 2.48 & 5.63 & 5.60 & 5.83 & 5.02 & 10.67 & 11.00 & 10.29 \\
\hline $\mathrm{Pb}$ & 0.12 & bdl & 0.12 & bdl & 0.10 & bdl & bdl & bdl & bdl & bdl & 0.11 & bdl & 0.11 \\
\hline As & bdl & bdl & bdl & bdl & bdl & bdl & bdl & bdl & bdl & bdl & 0.08 & bdl & 0.08 \\
\hline $\mathrm{Sb}$ & 0.12 & bdl & bdl & bdl & bdl & 0.12 & bdl & bdl & bdl & bdl & bdl & bdl & bdl \\
\hline $\mathrm{Sn}$ & 26.79 & 25.97 & 26.67 & 27.34 & 27.86 & 26.59 & 27.16 & 27.09 & 27.12 & 28.25 & 26.83 & 26.94 & 26.69 \\
\hline $\mathrm{Co}$ & 0.02 & 0.01 & 0.01 & 0.03 & bdl & 0.02 & 0.02 & 0.02 & 0.03 & bdl & 0.02 & 0.02 & bdl \\
\hline $\mathrm{Mn}$ & 0.01 & bdl & bdl & bdl & bdl & 0.01 & bdl & bdl & bdl & bdl & bdl & bdl & bdl \\
\hline $\mathrm{Hg}$ & 0.13 & bdl & 0.12 & 0.11 & 0.14 & 0.13 & 0.19 & 0.16 & 0.20 & 0.25 & 0.13 & bdl & 0.13 \\
\hline $\mathrm{Ag}$ & 0.12 & bdl & bdl & 0.03 & bdl & 0.13 & 0.03 & 0.03 & 0.03 & bdl & bdl & bdl & bdl \\
\hline $\mathrm{Ge}$ & 0.00 & bdl & 0.00 & 0.00 & bdl & 0.00 & bdl & bdl & 0.00 & 0.00 & bdl & bdl & bdl \\
\hline $\mathrm{Se}$ & 0.11 & 0.07 & 0.13 & bdl & bdl & 0.06 & bdl & bdl & bdl & bdl & 0.15 & bdl & 0.15 \\
\hline In & 0.99 & 1.47 & 1.30 & 0.50 & 0.15 & 1.05 & 0.20 & 0.21 & 0.19 & 0.06 & 0.11 & 0.14 & 0.07 \\
\hline $\mathrm{Cd}$ & 0.05 & bdl & bdl & 0.05 & bdl & 0.05 & 0.08 & 0.08 & 0.09 & 0.12 & 0.06 & bdl & 0.06 \\
\hline Total & 100.65 & 99.87 & 99.95 & 100.09 & 101.13 & 100.72 & 101.19 & 101.47 & 100.67 & 99.78 & 101.51 & 101.78 & 100.55 \\
\hline
\end{tabular}




\section{J. R. S. CARVALHO ETAL.}
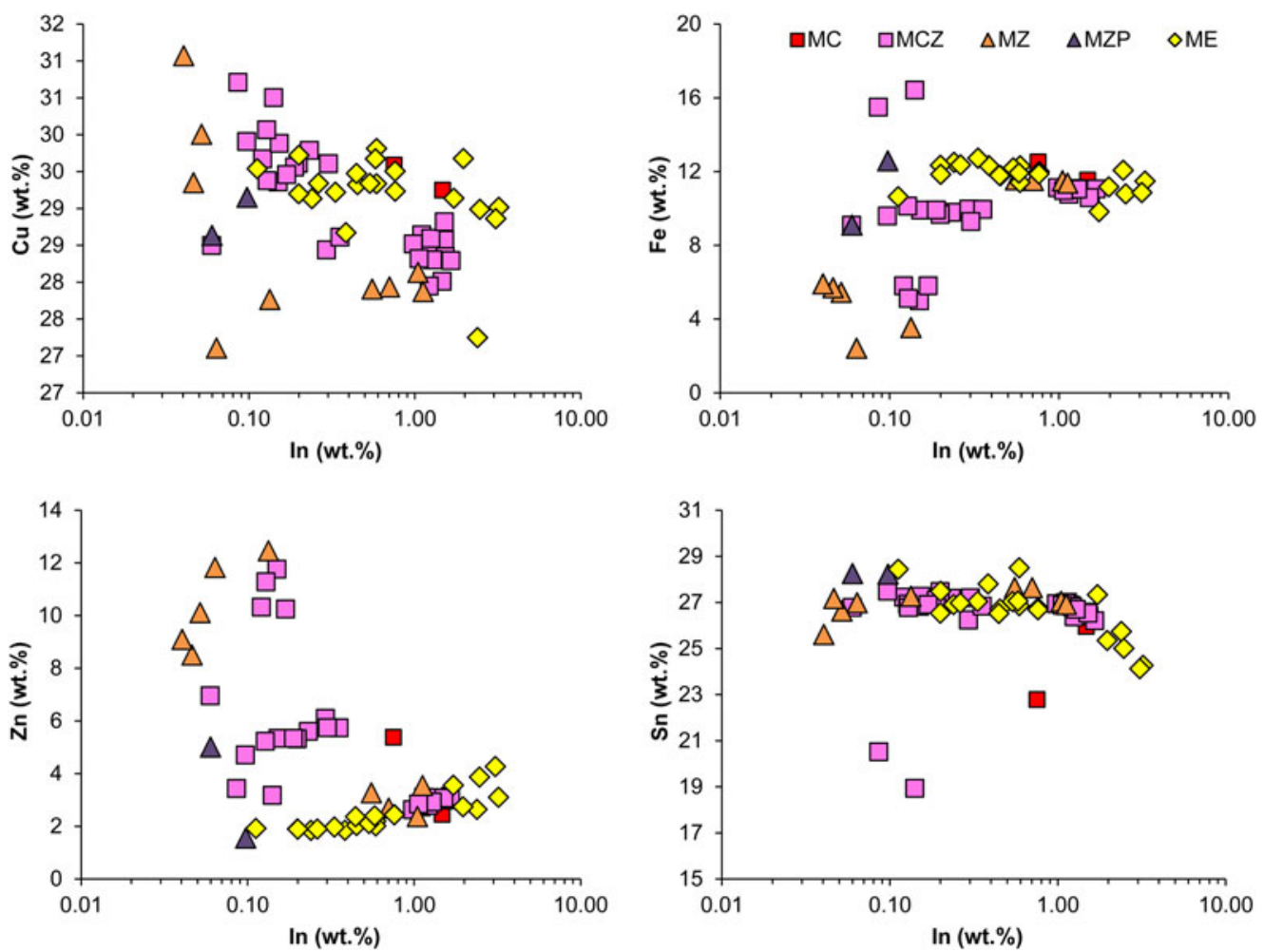

FIG. 10. Inter-elements plots for major and trace elements in stannite from the Neves-Corvo deposit. Abbreviations as in Table 11 .

stannite, there is no obvious relationship between these ratios and ore type. Measurable In concentrations (up to $0.35 \mathrm{wt} . \%$, averaging $0.20 \mathrm{wt} . \%$ ) were found in all ferrokesterite grains analysed, but the highest In content was measured in a ferrokesterite grain from the $\mathrm{MZ}$ ore at the Lombador orebody. Concentrations of other trace elements are generally low ( $<0.1$ wt. $\%)$, or $<$ MDL.

Finally, the kesterite crystals found in the MCZ and $\mathrm{MZ}$ ores show concentrations of $\mathrm{Fe}(2.42$ 5.91 wt.\%, averaging 5.06 wt.\%) and $\mathrm{Zn}$ (8.51 and 12.46 wt. $\%$, averaging 10.67 wt.\%) that are in excess relative to the ideal chemical formula of kesterite $\left(\mathrm{Cu}_{2} \mathrm{ZnSnS}_{4}\right)$. This is probably a consequence of intimate intergrowths with stannite. The $\mathrm{Fe} /(\mathrm{Fe}+\mathrm{Zn})$ ratios in kesterite range from 0.19 to 0.44 (averaging 0.36), but there is no obvious relationship between composition and ore type. The $\mathrm{Cu}$ and $\mathrm{Sn}$ concentrations reach up to $31.07 \mathrm{wt} . \%$ (averaging 29.34 wt.\% Cu) and 27.27 wt.\% (averaging $26.83 \mathrm{wt} . \% \mathrm{Sn}$ ), respectively. Indium concentrations of up to $0.17 \mathrm{wt} \%$ (averaging 0.11 wt. $\%$ In) were measured in over $90 \%$ of the kesterite grains analysed. As for stannite and ferroskesterite, concentrations of other trace elements are generally low $(<0.1 \mathrm{wt} . \%)$, or below MDL.

Roquesite and sakuraiite-roquesite intermediate phase

Roquesite is a relatively rare ore component, occurring mainly as sub-microscopic, anhedral to subhedral grains $(<10 \mu \mathrm{m})$ in the $\mathrm{MC}$ and $\mathrm{MCZ}$ ore types, in particular in those depicting secondary copper enrichment, either in close dependence of the chalcopyrite grain boundaries, or within sphalerite grains with chalcopyrite disease (Fig. 11). Roquesite crystals were also found locally in some ME ore samples associated with variable proportions of stannite-chalcopyritetetrahedrite-sphalerite that interstitially fill spaces between fractured and recrystallized pyrite and arsenopyrite crystals. The possible occurrence of an early, primary generation of roquesite cannot be precluded. However, most, if not all, roquesite crystals observed probably formed in response to a late episode of chemical reequilibration and 

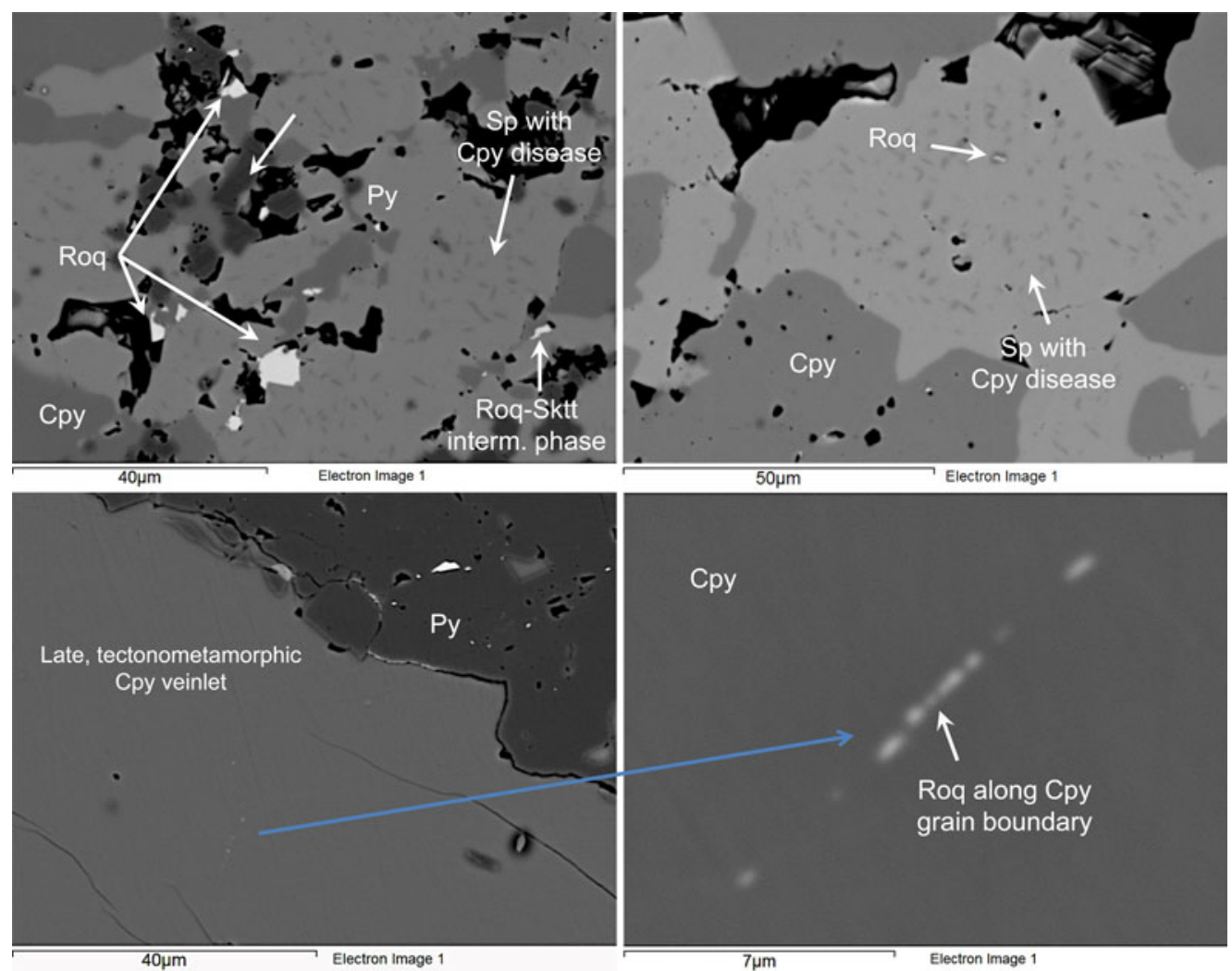

FIG. 11. High-resolution SEM-BSE images depicting the occurrence of roquesite (Roq) and the roquesite-sakuraiite (Roq-Sktt) intermediate phase associated with replacement (upper images) and late tectonometamorphic remobilization and reprecipitation along chalcopyrite (Cpy) grain boundaries (lower images).

homogenization. Outward migration of In accounted for crystallization of mineral inclusions and/or segregations towards the grain boundaries of recrystallized sulfides, such as chalcopyrite, sphalerite, stannite and pyrite. Roquesite is essentially stoichiometric, although detectable amounts of $\mathrm{Fe}$ (up to $1.82 \mathrm{wt} \%$, averaging 1.56 wt. $\% \mathrm{Fe}$ ), zinc (up to 1.07 wt.\%, averaging 0.71 wt. $\% \mathrm{Zn})$, and, to a lesser extent, Se (0.17 wt. $\%$ ) were found (Table 12).

The roquesite-sakuraiite intermediate phase was mostly found in the MCZ ore samples that show prominent tectonometamorphic copper enrichment. As roquesite, this phase also occurs in the dependence of the chalcopyrite grain boundaries, or within sphalerite grains with chalcopyrite disease (Fig. 11). The SEM-EDS semi-quantitative data indicate a widely variable range of $\mathrm{Cu}, \mathrm{Fe}, \mathrm{Zn}$ and In contents that may result either from incomplete segregation between roquesite and sakuraiite, or mixed analyses due to the small size of these inclusions. The In content ranges between 17.28 and $34.22 \mathrm{wt} . \%$, and the higher abundances occur in the MCZ ore samples.

\section{Galena}

Similarly to sphalerite and chalcopyrite, galena is essentially stoichiometric throughout the different ore types studied and generations identified. Notwithstanding, some analyses of galena have shown fairly reasonable concentrations of trace elements such as $\mathrm{Fe}, \mathrm{Cu}$ and $\mathrm{Bi}$, and significant $\mathrm{Se}$ (Table 13). Selenium substitutes for sulfur in the structure of galena, in particular in the $\mathrm{Cu}$-rich ore types (Fig. 12). The highest $\mathrm{Se}$ concentrations measured in galena (up to $15.6 \mathrm{wt} . \%$ ) were found in the cupriferous ore types (FC, MC and $\mathrm{MCZ}$ ). In these ore types $>70 \%$ of the galena grains analysed contain Se concentrations above MDL, as is the case for a high-grade ( $>35 \mathrm{wt} . \% \mathrm{Cu}$ ) $\mathrm{MC}$ ore lens 
TABLE 12. Representative EPMA and SEM-EDS analysis of roquesite and the roquesite-sakuraiite intermediate phase for the different ore types from the NevesCorvo deposit.

\begin{tabular}{|c|c|c|c|c|c|c|c|c|c|c|c|c|c|c|}
\hline \multicolumn{4}{|c|}{ EPMA } & \multicolumn{11}{|c|}{ SEM-EDS } \\
\hline & \multicolumn{3}{|c|}{ Roquesite } & \multicolumn{6}{|c|}{ Roquesite } & \multicolumn{5}{|c|}{ Roquesite-sakuraiite } \\
\hline & \multirow{2}{*}{\multicolumn{2}{|c|}{ ME }} & & & \multicolumn{5}{|c|}{$\mathrm{MC}$} & \multirow{2}{*}{$\begin{array}{c}\mathrm{MC} \\
6\end{array}$} & \multicolumn{4}{|c|}{$\mathrm{MCZ}$} \\
\hline & & & & Spectrum & 1 & 2 & 3 & 4 & 5 & & 7 & 8 & 9 & 10 \\
\hline S & 26.29 & 26.05 & 29.18 & S & 23.53 & 23.46 & 23.21 & 24.85 & 23.39 & 26.98 & 28.30 & 29.66 & 24.88 & 26.98 \\
\hline $\mathrm{Fe}$ & 1.44 & 1.43 & 1.82 & $\mathrm{Fe}$ & 0.65 & 1.07 & 0.94 & 1.92 & 1.48 & 11.45 & 10.72 & 10.96 & 2.47 & 4.02 \\
\hline $\mathrm{Cu}$ & 26.18 & 26.15 & 26.21 & $\mathrm{Cu}$ & 29.7 & 29.25 & 29.95 & 28.58 & 28.82 & 30.57 & 26.80 & 26.1 & 24.67 & 24.88 \\
\hline $\mathrm{Zn}$ & 0.52 & 0.55 & 1.07 & $\mathrm{Zn}$ & 1.91 & 3.16 & 1.79 & 5.43 & 4.54 & 9.79 & 16.95 & 14.1 & 13.75 & 11.95 \\
\hline $\mathrm{Sb}$ & bdl & bdl & 0.32 & In & 43.85 & 42.36 & 42.31 & 39.21 & 41.77 & 21.21 & 17.28 & 19.28 & 34.22 & 32.2 \\
\hline $\mathrm{Sn}$ & 0.24 & 0.35 & bdl & $\mathrm{Ag}$ & 0.6 & 0.71 & 0.8 & - & - & - & - & - & - & - \\
\hline Co & 0.02 & bdl & 0.01 & & & & & & & & & & & \\
\hline $\mathrm{Se}$ & bdl & bdl & 0.17 & & & & & & & & & & & \\
\hline In & 46.69 & 46.40 & 40.84 & & & & & & & & & & & \\
\hline $\mathrm{Cd}$ & bdl & bdl & 0.04 & & & & & & & & & & & \\
\hline Total & 101.37 & 100.92 & 99.67 & Total & 100 & 100 & 100 & 100 & 100 & 100 & 100 & 100 & 100 & 100 \\
\hline
\end{tabular}

MC - massive copper ore; MCZ - massive copper-zinc ore; ME - barren massive ore; bdl - below detection limit; '-’ not detected. 
TABLE 13. Average chemical composition of galena for the different ore types from the Neves-Corvo deposit.

FC - copper stockwork ore; FE - barren stockwork; FZ - zinc stockwork ore; MC - massive copper ore; MCZ - massive copper-zinc ore; MZ - massive zinc ore; MZP massive zinc-lead ore; $\mathrm{ME}$ - barren massive ore; bdl - below detection limit. 

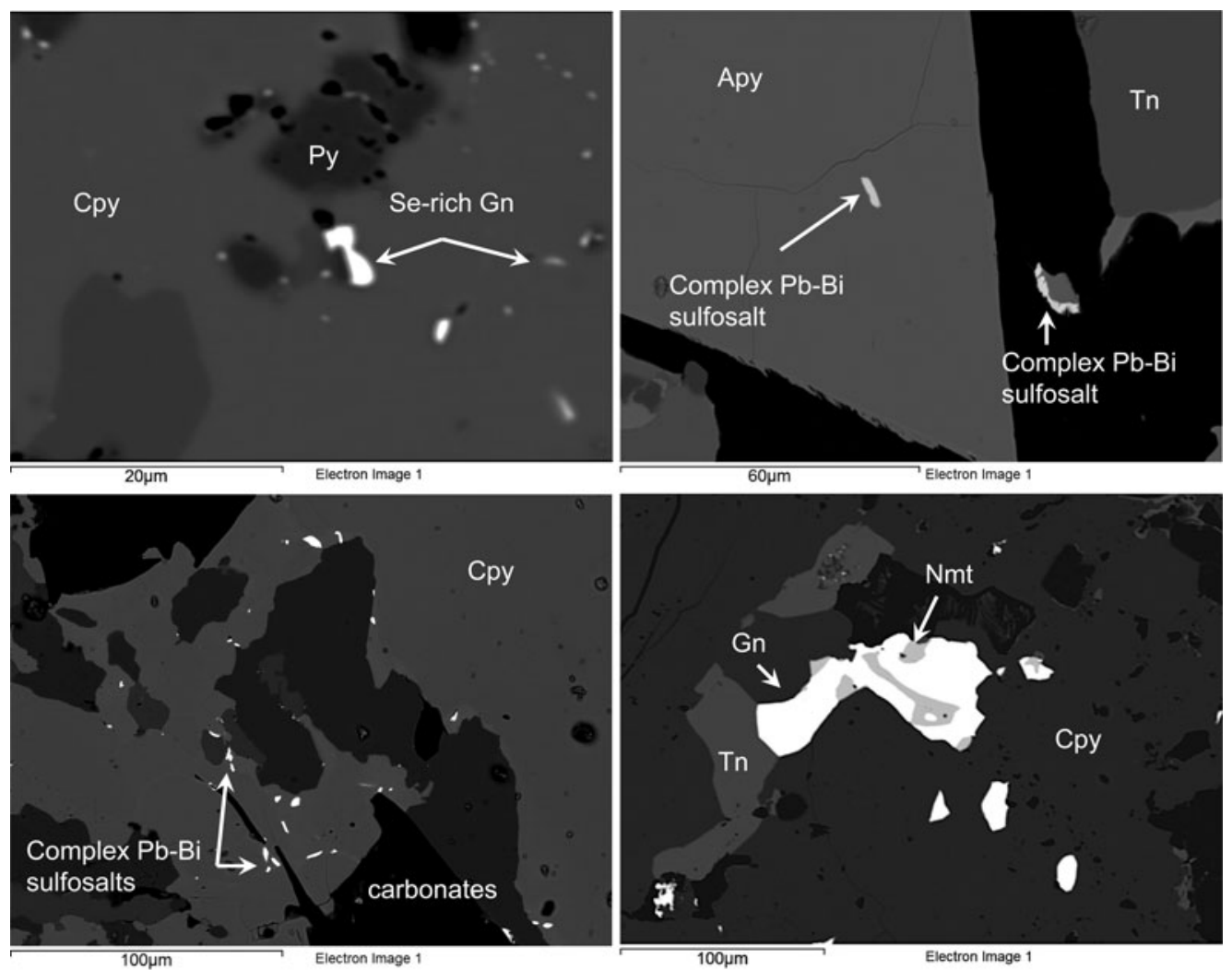

FIG. 12. High-resolution SEM-BSE images depicting the occurrence of Se-rich galena $(\mathrm{Gn})$ inclusion in chalcopyrite (Cpy), complex $\mathrm{Pb}-\mathrm{Bi}$ and $\mathrm{Bi}-\mathrm{Se}$ sulfosalts in arsenopyrite (Apy) and tennantite (Tn), and the occurrence of naumanite (Nmt) associated with galena.

discovered recently and exploited at the centralwest sector of the Lombador orebody. In the copper stockwork ore (FC), $55 \%$ of the galena grains analysed yielded Se concentrations above MDL, the maximum value being $3.8 \mathrm{wt} . \%$, whereas in the $\mathrm{MCZ}$ ore samples Se concentrations in galena reached up to $4.9 \mathrm{wt} . \% \mathrm{Se}$, in particular in the Zambujal orebody. In the remaining ore types studied, Se concentrations in galena mostly fall below MDL. Detectable Se concentrations were only occasionally measured in galena grains from the MZP ore (up to $0.31 \mathrm{wt} . \%$ ) and from the barren stockwork mineralization (FE; up to $0.47 \mathrm{wt} . \%$ ).

Iron, copper and zinc are relatively common trace elements in galena. On average, the Fe concentration found in galena grains is $0.30 \mathrm{wt} . \%$, whereas average $\mathrm{Cu}$ and $\mathrm{Zn}$ contents are 0.22 and 0.16 wt. $\%$, respectively. The maximum concentrations of these elements in galena grains reached up to 0.98 wt. $\% \mathrm{Fe}, 0.80$ wt. $\% \mathrm{Cu}$ and 0.78 wt.\% $\mathrm{Zn}$.
Detectable As (up to 0.68 wt.\%, averaging 0.22 wt. $\%$ ) was measured in $10 \%$ of the galena grains analysed. This is particularly true in the MCZ and MZP ore types, and is thought to result from very fine-grained arsenopyrite inclusions in the galena grains. Bismuth concentrations (up to 1.13 wt. $\%$, averaging $0.62 \%$ ) were only found in galena grains from high-temperature cupriferous ores, in particular in the $\mathrm{MC}$ ore samples. Concentrations of other trace elements in galena are relatively uniform and either very low $(<0.1$ wt. $\%)$, or below MDL.

Indium contents barely above MDL (0.02 wt.\%) were found only once in a grain of galena associated with remobilized chalcopyrite ( \pm tetrahedrite) in a MP ore sample. Again, extremely finegrained $(<5 \mu \mathrm{m})$ blebs and/or films of roquesite and/or roquesite-sakuraiite intermediate phases along the crystallographic directions of galena explain this anomalous result. 


\section{Complex $\mathrm{Pb}-\mathrm{Bi}$ and $\mathrm{Bi}-\mathrm{Se}$ sulfosalts}

Microprobe analyses performed on Se-bearing $\mathrm{Pb}-\mathrm{Bi}$ sulfosalts enabled identification of several species, including gustavite, cosalite, possible junoite, cannizzarite and wittite, and a number of other, unnamed $\mathrm{Pb}-\mathrm{Bi}$ and $\mathrm{Bi}-\mathrm{Se}$ intermediate phases (Supplementary Table S1, see below). Most of these minerals were found in FC ore samples, and occur as fine-grained intergrowths of leafy-shaped crystals associated with tetrahedrite, either in mineralized veins and veinlets, or associated with tectonicallyenriched MCZ ores (in particular from the Zambujal orebody). The latter occur as fine-grained $(\leq 10 \mu \mathrm{m})$ blebs close to the grain boundaries of annealed chalcopyrite, within tetrahedrite, or underlining the contact between chalcopyrite-tetrahedrite, and chalcopyrite-tetrahedrite-sphalerite (Fig. 12).

The chemical composition of gustavite deviates slightly from its ideal formula $\left(\mathrm{PbAgBi}_{3} \mathrm{~S}_{6}\right)$ due to a small depletion in $\mathrm{Pb}$ (16.26 wt.\%), coupled with relative enrichment in $\mathrm{Fe}(0.54$ wt.\%), $\mathrm{Cu}(0.50$ wt.\%), As (0.48 wt.\%) and $\mathrm{Sb}$ (1.86 wt.\%), which suggests the presence of fine-intergrowths of tetrahedrite and/or other mineral phases. Despite the depletion in lead, the $\mathrm{Pb} / \mathrm{Bi}$ ratio (0.31) and $\mathrm{Ag}$ contents measured $(8.17 \mathrm{wt} . \%)$ are within the compositional range reported for gustavite. The Se concentration measured is 0.15 wt. $\%$.

Probable junoite shows noticeable concentrations of trace elements such as $\mathrm{Ag}$ (up to $1.36 \mathrm{wt} . \%$, averaging $0.52 \mathrm{wt} . \%$ ), $\mathrm{Sb}$ (up to $0.89 \mathrm{wt} . \%$, averaging 0.87 wt.\%) and $\mathrm{Fe}$ (up to 0.21 wt. $\%$, averaging 0.14 wt.\%). This trace-element content deviates from the junoite ideal composition $\left(\mathrm{Pb}_{3} \mathrm{Cu}_{2} \mathrm{Bi}_{8}(\mathrm{Se}, \mathrm{S})_{16}\right)$ and may reflect fine intergrowths with tetrahedrite. Nevertheless, the calculated $\mathrm{Pb} / \mathrm{Bi}$ ratios obtained (0.31-0.38) are within the compositional range reported for junoite (Large and Mumme, 1975; Anthony et al., 2003). The $\mathrm{Pb}$ and $\mathrm{Cu}$ concentrations are relatively uniform, ranging from 18.01 to 19.46 wt.\% (averaging 18.55 wt.\% $\mathrm{Pb}$ ) and from 2.85 to 3.35 wt.\% (averaging 3.11 wt.\% Cu), respectively, whereas $\mathrm{Bi}$ concentrations are more variable (50.79-58.50 wt.\%, averaging $53.52 \mathrm{wt.} \%$ ). Selenium concentrations are equally variable, and range from 4.77 to 9.79 wt.\% (averaging 7.33 wt.\%). Concentrations of other trace elements are usually small ( $<0.1 \mathrm{wt} . \%)$ or below MDL.

The cannizzarite-like phase shows fairly significant concentrations of $\mathrm{Cu}$ (up to $1.44 \mathrm{wt} . \%$, averaging $0.83 \mathrm{wt} . \%$ ), $\mathrm{Ag}$ (up to $1.76 \mathrm{wt} . \%$, averaging $1.10 \mathrm{wt} . \%$ ), $\mathrm{Sb}$ (up to $0.78 \mathrm{wt} \%$, averaging $0.47 \mathrm{wt} . \%$ ), $\mathrm{Fe}$ (up to $0.40 \mathrm{wt} . \%$, averaging 0.23 wt.\%) and $\mathrm{Zn}$ (up to $0.15 \mathrm{wt} . \%$, averaging $0.10 \mathrm{wt.} \%)$. This trace-elements content represents a shift relative to the ideal composition of cannizzarite $\left(\mathrm{Pb}_{46} \mathrm{Bi}_{54} \mathrm{~S}_{127}\right.$; Anthony et al., 2003). Again, this suggests the presence of fine-grained intergrowths of tetrahedrite. Nevertheless, measured $\mathrm{Pb}$ (33.98-36.12 wt.\%, averaging 35.01 wt.\%) and Bi (43.01-44.42 wt.\%, averaging 43.70 wt.\%), as well as calculated $\mathrm{Pb} / \mathrm{Bi}$ ratios $(0.78-0.85)$ are within the compositional range for cannizzarite (cf. Mozgova et al., 1985; Borodaev et al., 2000; Anthony et al., 2003). Selenium concentrations are equally variable, ranging from 1.61 to $3.95 \mathrm{wt} . \%$ (averaging $2.65 \mathrm{wt} . \%$ ). Concentrations of other trace elements are generally low $(<0.1 \mathrm{wt} . \%)$, or below the minimum limits of detection.

A complex $\mathrm{Pb}$-Bi-sulfide with a composition close to wittite was analysed. It shows significant $\mathrm{Cu}, \mathrm{Ag}$ and $\mathrm{Sb}$ contents that deviate from the ideal composition of wittite $\left[\mathrm{Pb}_{3} \mathrm{Bi}_{4}(\mathrm{SeS})_{9}\right.$; Supplementary Table S1]. Nevertheless, the $\mathrm{Pb}$, $\mathrm{Bi}$ and $\mathrm{Se}$ concentrations, as well as its $\mathrm{Pb} / \mathrm{Bi}$ ratio (0.73) are within the compositional range admitted for wittite (cf. Mozgova et al., 1992; Anthony et al., 2003).

Other Se-bearing $\mathrm{Pb}-\mathrm{Bi}$ mineral phases analysed seem to correspond with intermediate compositions characterized by relatively uniform $\mathrm{Bi}$ and $\mathrm{S}$ concentrations, and widely variable contents of $\mathrm{Pb}, \mathrm{Cu}, \mathrm{Sb}, \mathrm{Ag}$ and $\mathrm{Se}$ (1.04-4.44 wt.\%; Supplementary Table S1). Concentrations of other trace elements are generally low $(<0.1 \mathrm{wt} . \%)$ or below $\mathrm{MDL}$, and the $\mathrm{Pb} / \mathrm{Bi}$ ratios for these phases range between 0.75 and 0.87 . Some analyses may correspond to nuffieldite with a chemical formula close to $\mathrm{Cu}_{4} \mathrm{~Pb}_{11} \mathrm{Bi}_{16} \mathrm{~S}_{7}$ as reported by Marcoux et al. (1996) for several IPB deposits.

Semi-quantitative SEM-EDS analyses of unknown $\mathrm{Pb}-\mathrm{Bi}$ and $\mathrm{Bi}-\mathrm{Se}$ phases found in $\mathrm{MCZ}$ ore samples gave very high $\mathrm{Se}$ concentrations (16.11-21.54 wt.\%, and 15.73-18.68 wt.\%, respectively; Supplementary Table S2).

\section{Discussion and conclusions}

This study has shown that, as in many other deposits (e.g. Auclair and Fouquet, 1987; Huston et al., 1995b; Hannington et al., 1999; SchwarzShampera, 2000; Layton-Matthews et al., 2013), In and $\mathrm{Se}$ are mainly associated with $\mathrm{Cu}$-rich ores in the Neves-Corvo deposit, which is consistent with joint transport and co-precipitation of In and Se from high-temperature, acidic, reduced, saline and $\mathrm{Cu}$-rich ore fluids (cf. Relvas et al., 2006a,b; Huston et al., 
2011). Sphalerite and chalcopyrite are the most important In carriers at Neves-Corvo deposit, their relative importance being a function of the ore types considered. Selenium is accommodated preferentially by galena, although arsenopyrite, chalcopyrite and pyrite also constitute significant Se carriers given their larger abundance in the deposit.

In the $\mathrm{Cu}$-rich ores, In partitioning between coexisting sphalerite and chalcopyrite is asymmetrical. Indium concentration in sphalerite is, on average, two to three times higher than in coexisting chalcopyrite, particularly in the $\mathrm{MCZ}$ ores where these two ore sulfides are both very abundant. In this ore type, when stannite co-exists with chalcopyrite and sphalerite, In concentrations are about nine times higher in stannite than in sphalerite, and 23 times higher in stannite than in chalcopyrite. In the MC ore samples, the partition coefficients are slightly lower, but these tendencies remain. Although the In concentrations in the ore sulfides from the $\mathrm{Zn}$ rich ores are significantly lower, the overall partitioning behaviour described above is still maintained. However, tectonometamorphic In enrichments, which can reach $500 \%$ locally, distort the described partitioning between coexisting ore minerals.

Regarding Se, its partition coefficient in galena is extremely high, in particular in the richer MC ores $(>35$ wt. $\% \mathrm{Cu})$. In this type of ore, Se concentrations can be almost 130 times higher in galena than in chalcopyrite, 87 times higher in galena than in pyrite and 27 times higher in galena than in arsenopyrite. In the FC ore, Se concentration is up to 33 times higher in galena than in chalcopyrite and pyrite, whereas in the MCZ ore, Se concentration is up to 21 times higher in galena than in chalcopyrite and sphalerite. In the MZP ore type, Se concentrations are roughly three times higher in galena than in coexisting sphalerite.

Although roquesite, naumannite and complex $\mathrm{Pb}-\mathrm{Bi}$ sulfo- and selenosalts constitute the more Inand Se-rich ore phases found, their overall low abundance and small size imply that these do not represent important In- and Se-carriers at the deposit scale. Given the large abundance of chalcopyrite in the deposit, its comparatively low but fairly constant In content, together with the occurrence of micro- and, probably, nano-inclusions of roquesite and/or roquesite-sakuraiite intermediate phases along borders of its recrystallized grains, chalcopyrite is probably the most important In carrier at the deposit scale, despite the fact that its In content is less than that of coexisting sphalerite in the $\mathrm{Cu}-\mathrm{Zn}$ massive ores (MCZ).
The average In concentrations reported for chalcopyrite and sphalerite from the copper concentrate (417 and $611 \mathrm{ppm}$, respectively), and from the zinc concentrate (560 and $246 \mathrm{ppm}$, respectively) produced at the Neves-Corvo mine (Frenzel et al., 2015) are quite consistent with the conclusions of this study. The sphalerite present in the copper concentrate of Neves-Corvo comes mostly from the MCZ type of ore, where the In concentration in sphalerite has been shown to be maximal. Conversely, in the Zn-rich ore types, which are the main sources of sphalerite for the zinc concentrate at Neves-Corvo, sphalerite has very low In contents, whereas the chalcopyrite present there is mainly the result of tectonometamorphic copper remobilization, which, as shown, represents a major mechanism of In enrichment.

In conclusion, the various types of $\mathrm{Cu}$-rich ores (MCZ, MC and FC) constitute the main sources of In in the deposit, and therefore the copper concentrate represents an industrial product that could (and should) be valorized for this critical byproduct. The MCZ ores, in particular, combine in a favourable way two of the main factors controlling the In distribution in the deposit: favourable sourcing ( $\mathrm{In}-\mathrm{Cu}$ metallogenetic affinity), and favourable mineral allocation (In-sphalerite crystallochemical affinity). In addition to this, some zincrich ores could possibly also represent important In resources, especially in tectonically deformed settings. There, sphalerite shows fairly reasonable and constant In abundances, in particular in zones where the $\mathrm{Cu}$ grade was enhanced by tectonometamorphic remobilization, which favoured significant In enrichment. This means that there is also potential for the recovery of In from an 'In-enriched' zinc concentrate provided that it could be produced selectively either from ores exploited in $\mathrm{MCZ}$ ore zones, or from $\mathrm{Zn}$-rich ores exploited from particularly deformed settings within the deposit.

\section{Acknowledgements}

The work of JRSC was supported by a $\mathrm{PhD}$ scholarship from Fundação para a Ciência e Tecnologia (FCT; SFRH/BD/74047/2010). The study is a contribution to ZHINC research project (PTDC/CTE-GIX/114208/2009), and was also supported by FCT project UID/GEO/50019/2013 - IDL. Thorough reviews by Fernando Tornos and an anonymous reviewer, and comments, insightful suggestions and encouragement by the editors, John Bowles and Nigel Cook, contributed significantly to improving the quality of the manuscript, and are 
greatly appreciated and acknowledged. The authors affiliated with Somincor-Lundin Mining wish to thank the Administration Board for permission to publish this paper. Steve Scott, Yanan Liu, Duane Smythe, George Kretschmann from the University of Toronto, and Filipa Marques from the University of Bergen are acknowledged for their various contributions.

\section{Supplementary material}

To view supplementary material for this article, please visit https://doi.org/10.1180/minmag.2017.081.079

\section{References}

Albouy, L., Conde, L.N., Foglierini, F., Leca, X., Morikis, A., Callier, L., Carvalho, P. and Songy, J.C. (1981) Le gisement de sulfures massifs polymétalliques de NevesCorvo (Baixo Alentejo, Sud Portugal): Chronique des Mines et de la Recherche Minière, 49, 6-27.

Anthony, J.W., Bideaux, R.A., Bladh, K.W. and Nichols, M.C. (2003) Handbook of Mineralogy, Volume I Elements, Sulfides, Sulfosalts. Mineral Data Publishing, Tucson, Arizona, USA, 588 pp.

Auclair, G., Fouquet, Y. and Bohn, M. (1987) Distribution of selenium in high-temperature hydrothermal sulfide deposits at $13^{\circ}$ North, East Pacific Rise. The Canadian Mineralogist, 25, 577-587.

Bachmann, K., Frenzel, M., Krause, J. and Gutzmer, J. (2017) Advanced identification and quantification of In-bearing minerals by scanning electron microscopebased image analysis. Microscopy and Microanalysis, 23, 527-537.

Bente, K. and Doering, T. (1995) Experimental studies on the solid state diffusion of $\mathrm{Cu}+\mathrm{In}$ in $\mathrm{ZnS}$ and on "Disease", DIS (Diffusion Induced segregations), in sphalerite and their geological applications. Mineralogy and Petrology, 53, 285-305.

Benzaazoua, M., Marion, P., Liouville-Bourgeois, L., Joussemet, R., Houot, R., Franco, A. and Pinto, A. (2002) Mineralogical distribution of some minor and trace elements during laboratory flotation processing of Neves-Corvo ore (Portugal). International Journal of Mineral Processing, 66, 163-181.

Benzaazoua, M., Marion, P., Pinto, A., Migeon, H. and Wagner, F.E. (2003) Tin and indium mineralogy within selected samples from the Neves Corvo ore deposit (Portugal): a multidisciplinary study. Minerals Engineering, 16, 1291-1302.

Borodaev, Y.S., Garavelli, A., Garbarino, C., Grillo, S.M., Mozgova, N.N., Organova, N.I., Trubkin, N.V. and Vurro, F. (2000) Rare sulfosalts from Vulcano, aeolian islands, Italy. III. Wittite and Cannizzarite. The Canadian Mineralogist, 38, 22-34.
Carvalho, J.R.S. (2016) Zinc Metallogenesis, and Indium and Selenium Distribution at the Neves Corvo Deposit, Iberian Pyrite Belt, Portugal. PhD thesis, University of Lisbon, Portugal, 817 pp.

Carvalho, P. and Ferreira, A. (1994) Geologia de NevesCorvo: estado actual do conhecimento: APIMINERAL. Simpósio de Sulfuretos Polimetálicos da Faixa Piritosa Ibérica, Évora, Outubro, Portugal Mineral, 4th, no. 33, p. 1-5, no. 36, p. 7-8.

Carvalho, J.R.S., Fernandes, A.S., Moreira, B.B., Pinto, Á.M.M., Relvas, J.M.R.S., Pacheco, P., Pinto, F. and Fonseca, R. (2013) Hydrothermal alteration and ore mineralogy at the Lombador Massive Sulphide Orebody, Neves Corvo, Portugal: an on-going study. Pp. 514-517 in: Mineral Deposit Research for a HighTech World, 2. 12th SGA Biennal Meeting, Proceedings.

Carvalho, J.R.S., Relvas, J.M.R.S., Pinto, A.M.M., Marques, F., Rosa, C.J.P., Pacheco, N. and Fonseca, R. (2014) New insights on the metallogenesis of the Neves Corvo deposit: mineralogy and geochemistry of the zinc-rich Lombador orebody. Goldschmidt Conference Abstracts, 2014, p. 353.

Carvalho, J.R.S., Relvas, J.M.R.S., Pinto, Á.M.M., Pacheco, N., Fonseca, R., Santos, S., Caetano, P., Reis, T. and Gonçalves, M. (2015) On the indium and selenium distribution and mineral allocation at the Neves Corvo deposit, Portugal. Pp. 695-698 in: Mineral Resources in a Sustainable World, 2. 13th SGA Biennal Meeting, Proceedings.

Cook, N.J., Ciobanu, C.L., Pring, A., Skinner, W., Shimizu, M., Danyushevsky, L., Saitni-Eidukat, B. and Melcher, F. (2009) Trace and minor elements in sphalerite: a LA-ICPMS study. Geochemica et Cosmochimica Acta, 73, 4761-4791.

Frenzel, M., Bachmann, K., Krause, J., Carvalho, J.R.S., Relvas, J.M.R.S., Pacheco, N. and Gutzmer, J. (2015) Mineralogical deportment of indium in the NevesCorvo deposit - implications for recovery and extraction. SEG 2015 Meeting, World-Class Ore Deposits: Discovery to Recovery. Hobart, Tasmania, Australia.

Frenzel, M., Hirsch, T. and Gutzmer, J. (2016) Gallium, germanium, indium and other trace and minor elements in sphalerite as a function of deposit type A meta-analysis. Ore Geology Reviews, 76, 52-78.

Gaspar, O. (2002) Mineralogy and sulphide mineral chemistry of the Neves Corvo Ores, Portugal: Insight into their genesis. The Canadian Mineralogist, $\mathbf{4 0 ,}$ 611-636.

George, L.L., Cook, N.J. and Ciobanu, C.L. (2016) Partitioning of trace elements in co-crystallised sphalerite-galena-chalcopyrite hydrothermal ores. Ore Geology Reviews, 77, 97-116.

Gurmendi, A.C. (2013) The Mineral Industry of Portugal. USGS 2011 Mineral Yearbook. Accessed at http://minerals.usgs.gov/minerals/pubs/country/ 2011/myb3-2011-po.pdf 
Hannington, M.D., Peter, J. and Scott, S.D. (1986) Gold in sea-floor polymetallic sulfide deposits. Economic Geology, 81, 1867-1883.

Hannington, M.D., Bleeker, W. and Kjaersgaard, I. (1999) Sulfide mineralogy, geochemistry, and ore genesis of the Kidd Creek Mine: Part I. The North, Central, and South Orebodies. Pp. 163-224 in: Economic Geology Monograph 10: The Giant Kidd Creek Volcanogenic Massive Sulfide Deposit (M.D. Hannington, T. Barrie, editors). Western Abitibi Subprovince, Canada.

Healy, R.E. and Petruk, W. (1992) Graphic galenaclausthalite solid solution in low Fe sphalerite from the Trout Lake massive sulfide ores, Flin Flon, Manitoba. Economic Geology, 87, 1906-1910.

Herzig, P.M., Petersen, S. and Hannington, M.D. (1998) 4. Geochemistry and sulfur-isotopic composition of the TAG hydrothermal mound, mid-Atlantic Ridge, $26^{\circ} \mathrm{N}$. Pp. 47-69 in: Proceedings of the Ocean Drilling Program, Scientific Results, 158 (O.M. Herzig, S.E. Humphris, D.J. Miller, R.A. Zeirenberg, editors). Texas A\&M University, College Station, Texas, USA.

Huston, D.L., Sie, S.H. and Suter, G.F. (1995a) Selenium and its importance to the study of ore genesis: the theoretical basis and its application to volcanic-hosted massive sulfide deposits using pixeprobe analysis. Nuclear Instruments and Methods in Physis Research, 104, 476-480.

Huston, D.L., Sie, S.H., Suter, G.F. and Cooke, D.R., Both (1995b) Trace elements in sulfide minerals from Eastern Australian volcanic-hosted massive sulfide deposits: Part I: Proton microprobe analyses of pyrite, chalcopyrite, and sphalerite, and Part II. Selenium levels in pyrite: comparison with $\delta 34 \mathrm{~S}$ values and implication for the source of sulfur in volcanogenic hydrothermal systems. Economic Geology, 90, 1167-1196.

Huston, D.L., Relvas, J.M.R.S., Gemmell, J.B. and Drieberg, S. (2011) The role of granites in volcanichosted massive sulphide ore-forming systems: an assessment of magmatic-hydrothermal contributions. Mineralium Deposita, 46, 473-507.

Johan, Z. (1988) Indium and germanium in the structure of sphalerite: and example of coupled substitution with copper. Mineralogy and Petrology, 39, 211-229.

Jorge, R.C.G.S., Pinto, A.M.M., Tassinari, C.C.G., Relvas, J.M.R.S. and Munhá, J. (2007) VHMS metal sources in the Iberian Pyrite Belt: new insights from $\mathrm{Pb}$ isotope data. Pp. 1097-1100 in: Digging Deeper (C.J. Andrew et al., editors). Special Publication of the Irish Association for Economic Geology.

Kaufmann, B. (2006) Calibrating the Devonian time scale: a synthesis of U-Pb ID-TIMS ages and conodont stratigraphy. Earth-Sciences Reviews, 76, 175-190.

Large, R.R. and Mumme, W.G. (1975) Junoite, "wittite", and related seleniferous bismuth sulfosalts from Juno Mine, northern Territory, Australia. Economic Geology, 70, 369-383.
Layton-Matthews, D., Leybourne, M.I., Peter, J.M., Scott, S.D., Cousens, B. and Eglington, B.M. (2013) Multiple sources of selenium in ancient seafloor hydrothermal systems: Compositional and $\mathrm{Se}, \mathrm{S}$, and $\mathrm{Pb}$ isotopic evidence from volcanic-hosted and volcanic-sedimenthosted massive sulfide deposits of the Finlayson Lake District, Yukon, Canada. Geochemica et Cosmochimica Acta, 117, 313-331.

Leca, X., Ribeiro, A., Oliveira, J.T., Silva, J.B., Albouy, L., Carvalho, P. and Merino, H. (1983) Cadre Géologique des Minéralisations de Neves-Corvo, Baixo Alentejo, Portugal: Lithostratigraphie, paléogeographie et téctonique. Bureau Recherches Geologiques Miniéres Memoires, 121, 79.

Leca, X., Albouy, L., Aye, F. and Picot P. (1985) Caractéristiques principales du gisement de NevesCorvo(Portugal): Chron. Chronique des Mines et de la Recherche Minière, 481, 53-58.

Marcoux, E., Moëlo, Y. and Leistel, J.M. (1996) Bismuth and cobalt minerals as indicators of stringer zones to massive sulphide deposits, Iberian Pyrite Belt. Mineralium Deposita, 31, 1-26.

Moura, M.A., Botelho, N.F. and Carvalho de Mendonça, F. (2007) The indium-rich sulfides and rare arsenates of the Sn-In-mineralized Manngabeira A-Type Granite, Central Brazil. The Canadian Mineralogist, 45, 485-496.

Mozgova, N.N., Kuzmina, O.V., Organova, N.I. and Laputina, I.P. (1985) New data on sulphosalt assemblages at Vulcano (Italy). Rendiconti Della Società Di Mineralogia e Petrologia, 40, 277-283.

Munhá, J. (1990) Metamorphic evolution of the south Portuguese/Pulo do Lobo zone. Pp. 363-368 in: PreMesozoic geology if Iberia (R.D. Dallmeyer, E. Martinez Garcia, editors). Springer-Verlag, Berlin, Heidelberg, New York.

Munhá, J., Relvas, J.M.R.S., Barriga, F.J.A.S., Conceição, P., Jorge, R.C.G.S., Mathur, R., Ruiz, J. and Tassinari, C.C.G. (2005) Os isotopes systematics in the Iberian Pyrite Belt. Pp. 663-666 in: Mineral Deposit Research: Meeting the Global Challenge (J. Mao, F. P. Bierlein, editors). Springer, Berlin.

Ohta, E. (1989) Occurrence and chemistry of indiumcontaining minerals from the Toyoha mine, Hokkaido, Japan. Mining Geology, 39, 355-372.

Oliveira, J.T. (1990) Stratigraphy and synsedimentary tectonism. South Portuguese Zone. Pp. 348-362 in: Pre-Mesozoic Geology if Iberia (R.D. Dallmeyer, E. Martinez Garcia, editors). Springer-Verlag, Berlin Heidelberg, New York.

Oliveira, J.T., Carvalho, P., Pereira, Z., Pacheco, N., Fernandes, J.P. and Korn, D. (1997) Stratigraphy of the Neves-Corvo mine region. Pp. 86-87 in: Society of Economic Geologists, Neves-Corvo Field Conference. Lisbon, Portugal, May 11-14.

Oliveira, J.T., Pereira, Z., Carvalho, P., Pacheco, N. and Korn, D. (2004) Stratigraphy of the tectonically 
imbricated lithological succession of the Neves Corvo mine area, Iberian Pyrite Belt, Portugal. Mineralium Deposita, 39, 422-436.

Pacheco, N., Carvalho, P. and Ferreira, A. (1998) Geologia da Mina de Neves Corvo e do vulcanismo do anticlinório de Panóias - Castro Verde. Pp. 1-5; 36, 7-8 in: Guia das Excursões: V Congresso Nacional de Geologia, 33 (J.T. Oliveira, R. Dias, editors). National Laboratory of Energy and Geology, Lisbon.

Pereira, Z., Pacheco, N. and Oliveira, J.T. (2004) A case applied palynology: dating the lithological succession of the Neves Corvo mine, Iberian Pyrite Belt, Portugal. Pp. 345-354 in: Proceedings of the XVth ICCP Stratigraphy (Th.E. Wong, editor). R.D. Academy Arts and Sciences.

Pinto, Á.M.M., Ferreira, A., Bowles, J.F.W. and Gaspar, O. (1997) Mineralogical and textural characterization of the Neves-Corvo ores. in: Metallogenetic Implications. Society of Economic Geologists, Neves-Corvo Field Conference, Lisbon, Portugal, May 11-14, p. 90.

Pinto, Á.M.M., Relvas, J.M.R.S., Carvalho, J.R.S. and Liu, Y. (2014) High-tech metals in the zinc-rich massive ores of the Neves Corvo Deposit. Comunicações Geológicas, 1010, 825-828.

Reiser, F.K.M., Guimarães, F., Pinto, Á.M.M., Matos, J. X., Carvalho, J.R.S., de Oliveira, D.P.S. and Rosa, D. R.N. (2009) Germanium-rich chalcopyrite from the Barrigão remobilised vein deposit, Iberian Pyrite Belt, Portugal. Smart Science for Exploration and Mining, 2, 424-426.

Relvas, J.M.R.S. (2000) Geology and metallogenesis at the Neves Corvo deposits, Portugal. Unpublished PhD thesis, University of Lisbon, 319 pp.

Relvas, J.M.R.S., Tassinari, C.C.G., Munhá, J. and Barriga, F.J.A.S. (2001) Multiple sources for oreforming fluids in the Neves-Corvo VHMS deposit of the Iberian Pyrite Belt (Portugal): strontium, neodymium and lead isotope evidence. Mineralium Deposita, 36, 416-427.

Relvas, J.M.R.S., Barriga, F.J.A.S., Pinto, A., Ferreira, A., Pacheco, N., Noiva, P., Barriga, G., Baptista, R., Carvalho, D., Oliveira, V., Munhá, J. and Hutchinson, R.W. (2002) The Neves-Corvo deposit, Iberian Pyrite Belt, Portugal: impacts and future, 25 years after the discovery. Pp. 155-176 in: Integrated Methods for Discovery: Global Exploration in the 21st Century (R. Goldfarb, J. Nielsen, editors). Society of Economic Geologists Special Publication, Vol. 9.

Relvas, J.M.R.S., Barriga, F.J.A.S., Ferreira, A., Noiva, P., Pacheco, N. and Barriga, G. (2006a) Hydrothermal alteration and mineralization in the Neves-Corvo volcanic-hosted massive sulfide deposit, Portugal: I. Geology, mineralogy, and geochemistry. Economic Geology, 101, 753-790.
Relvas, J.M.R.S., Barriga, F.J.A.S. and Longstaffe, F. (2006b) Hydrothermal alteration and mineralization in the Neves-Corvo volcanic-hosted massive sulfide deposit, Portugal: II. Oxygen, hydrogen and carbon isotopes. Economic Geology, 101, 791-804.

Rosa, C.J.P., McPhie, J., Relvas, J.M.R.S., Pereira, Z. and Pacheco, N. (2005) Felsic pyroclastic and effusive volcanic facies hosting the Neves-Corvo massive sulfide deposit, Iberian Pyrite Belt, Portugal. Pp. 691-694 in: Mineral deposit research: meeting the global challenge, v. 1, Proceedings of the 8th Biennial SGA Meeting, Beijing, China, August 2005 (J. Mao, F. P. Bierlein, editors). Springer, Berlin.

Rosa, C.J.P., McPhie, J., Relvas, J.M.R.S., Pereira, Z., Oliveira, T. and Pacheco, N. (2008) Facies analyses and volcanic setting of the giant Neves Corvo massive sulphide deposit, Iberian Pyrite Belt, Portugal. Mineralium Deposita, 43, 449-466.

Schwarz-Schampera, U. (2000) Indium-tin association in volcanogenic massive sulfide deposits: Evidences from active seafloor hydrothermal systems and ancient massive sulfide deposits on land. PhD thesis, TU Bergakademie Freiberg, Germany, 508 pp.

Schwarz-Schampera, U. and Herzig, P.M. (2002) Indium: Geology, Mineralogy, and Economics. Springer, Heidelberg, Germany, 257 pp.

Serranti, S., Ferrini, V. and Masi, U. (1997) Micro-PIXE Analysis of Trace Elements in Ore Minerals from the Neves-Corvo Deposit (Portugal). Preliminary Report. Society of Economic Geologists, NevesCorvo Field Conference, Lisbon, Portugal, May 11-14, p. 109.

Serranti, S., Ferrini, V., Masi, U. and Cabri, L.J. (2002) Trace-element distribution in cassiterite and sulfides from rubané and massive ores of the Corvo deposit, Portugal. The Canadian Mineralogist, 40, $815-835$.

Silva, J.B., Oliveira, J.T. and Ribeiro, A. (1990) South Portuguese Zone. Structural outline. Pp. 348-362 in: Pre-Mesozoic Geology of Iberia (R.D. Dallmeyer, E. Martinez Garcia, editors), Springer-Verlag, Berlin, Heidelberg, New York.

Silva, J.B., Ribeiro, A., Fonseca, P., Oliveira, J.T., Pereira, Z., Fernandes, P., Munhá, J., Barriga, F.J.A.S., Relvas, J.M.R.S., Carvalho, P. et al. (1997) Tectonostratigraphic overview of Neves Corvo Mine in the context of the Variscan Orogeny. Neves Corvo Field Conference Abstracts, Society of Economic Geologists, Lisbon, p. 88.

Sinclair, W.D., Kooiman, G.J.A., Martin, D.A. and Kjarsgaard, I.M. (2006) Geology, geochemistry and mineralogy of indium resources at Mount Pleasant, New Brunswick, Candada. Ore Geology Reviews, 28, $123-145$. 